\title{
Same, different and other as comparative adjectives - A uniform analysis based on French
}

\section{Citation}

Charnavel, Isabelle. 2015. "Same, Different and Other as Comparative Adjectives - A Uniform Analysis Based on French." Lingua 156 (March): 129-174. doi:10.1016/j.lingua.2014.12.005. .

\section{Published Version}

doi:10.1016/j.lingua.2014.12.005

\section{Permanent link}

http://nrs.harvard.edu/urn-3:HUL.InstRepos:25506702

\section{Terms of Use}

This article was downloaded from Harvard University's DASH repository, and is made available under the terms and conditions applicable to Open Access Policy Articles, as set forth at http:// nrs.harvard.edu/urn-3:HUL.InstRepos:dash.current.terms-of-use\#OAP

\section{Share Your Story}

The Harvard community has made this article openly available.

Please share how this access benefits you. Submit a story.

Accessibility 


\title{
Same, Different and Other as Comparative Adjectives \\ A Uniform Analysis based on French \\ Isabelle Charnavel (Harvard University)
}

\begin{abstract}
The goal of this article is to provide a uniform and non-specific analysis for all constructions involving terms expressing similarity and difference (sidi terms) such as same, different or other in French. Beyond theoretical economy, the motivation for this enterprise is based on crosslinguistic evidence showing a unique term for same through all constructions in many unrelated languages. The proposed analysis does not resort to any specific mechanism, but relates sidi terms to both comparatives and relational terms: sidi terms are assumed to be relational adjectives that are complemented by DPs or comparative clauses; in short, they are analyzed as comparatives of individuals. The diversity of constructions does not derive from multiple lexical entries, but from the presence of silent structures: in particular, the comparative clause can be fully or partially elided, and the phrasal or clausal complement of sidi terms can include a silent underspecified pronoun, which can get a pronominal, reflexive, reciprocal or vaguer interpretation. The behavior of sidi terms in islands argues for the presence of silent structures.
\end{abstract}

\section{Keywords}

same / different / other

comparative

relational term

ellipsis

underspecified pronoun 


\section{Introduction}

Adjectives such as different, same or other express similarity and difference (they will henceforth be called sidi terms): they make a comparison between elements. For instance in (1), different compares Lucie (the compared element) with Claire (the standard).

(1) Lucie is different from Claire.

These adjectives appear in various constructions as illustrated below with French différent. The first group of constructions involves a linker (e.g. de 'from', que 'than, as, that') and the standard (underlined) is at least partially explicit.

(1)' Lucie est différente de Claire.

'Lucie is different from Claire.'1

(2) J'ai vu un film différent de ce film-là.

'I watched a movie different from this one.'

(3) Paul a vu un film différent de ce que proposait Marie.

'Paul watched a different movie than what Marie proposed.

(4) Paul a vu un film différent de Marie.

'Paul watched a different movie than Marie.

(5) J'ai regardé un film différent d'hier.

'I watched a different movie than yesterday.'

The second set of constructions does not exhibit any linker. In this case, the standard is implicit and can be retrieved based on sentence-external elements (underlined in (6)-(7)) or sentence-internal ones (underlined in (8)-(13)).

(6) Lucie est allée voir Frida hier. Moi, j'ai vu un film différent.

'Lucie watched Frida yesterday. As for me, I watched a different movie.'

(7) [Watching a trailer] C'est un film différent que j'avais vu.

'It is a different movie that I had watched.'

(8) Ces films sont différents.

'These movies are different.'

\footnotetext{
1 Throughout the article, I will provide English translations that are as close as possible to the French sentences to make the French structure transparent. Note that I will not specify grammaticality judgments for the English translations, but only for the French sentences.
} 
(9) J'ai vu des films différents pendant les vacances.

'I watched different movies during the holidays.'

(10) Les critiques ont vu des films différents.

'The critics watched different movies.'

(11) Par rapport à la semaine dernière, chaque enfant est différent aujourd'hui. 'As compared to last week, each child is different today.'

(12) Chaque critique a vu un film différent. 'Each critic watched a different movie.'

(13) Paul et Claire ont vu un film différent. 'Paul and Claire watched a different movie.'

To the best of my knowledge, most previous analyses (e.g. Heim: 1985, Dowty: 1985, Carlson: 1987, Moltmann: 1992, Barker: 2007) concentrate on so-called internal readings such as (10), (12) and (13) and propose specific mechanisms to account for them without relating them to the other cases or to other expressions of the language. A few studies (e.g. Beck: 2000, Brasoveanu: 2011) relate some of these constructions to each other, but not all of them: they assume the existence of several lexical entries for e.g. different. Moreover, the previous accounts usually focus on a single sidi term (mostly same or different).

The goal of this paper is to present a uniform analysis for all these constructions in French, which does not appeal to specific mechanisms: I will commit myself to a single lexical entry for each sidi term - différent, même and autre, and derive the diversity of constructions from mechanisms that are already necessary to account for other elements of the language, i.e. relational terms and comparatives. Beyond theoretical economy, the main motivation for this enterprise is empirical: in many languages from different language families that I have surveyed (see appendix), a single word is used for same under all its uses.

In a nutshell, the variety of constructions will be derived from the presence of silent structures. In particular, I hypothesize that sidi terms are relational adjectives that can be complemented by comparative clauses, and these comparative clauses can be partially or fully elided. This hypothesis will be supported by the behavior of sidi terms in islands.

As a preview, here is the gist of the analysis. Différent is a relational adjective that selects two individuals, just like other relational terms (e.g. enemy, neighbor). The first individual (the compared element) is projected as a DP and the second one (the standard) can correspond to a DP or a CP just like comparatives; a preposition (linker) occurs between the DP/CP and the sidi term as is standard with relational terms (e.g. 
enemy of, far from). Moreover, the standard can be partially or completely silent: the comparative clause can be elided, and the DP can be silent and underspecified so that it is pragmatically interpreted as a pronoun, a reflexive or a reciprocal as is the case with relational terms or some elements like French clitic se or pronouns.

The combination of these ingredients yields constructions (1)-(13) in the following way; $X$ symbolizes a silent DP and the index shows its salient pragmatic interpretation. (1)'-(3) simply involve explicit DPs as standards, but in (6)-(11), the standard is a silent DP that is underspecified and can be pragmatically interpreted as a pronoun, a reciprocal or a reflexive.

(6)' Lucie est allée voir Frida hier. Moi, j'ai vu un film différent de $X_{\text {pronoun(anaphoric). }}$

'Lucie watched Frida yesterday. As for me, I watched a different movie from X pronoun(anaphoric).'

(7)' [Watching a trailer] C'est un film différent de $\mathrm{X}_{\text {pronoun(deictic) }}$ que j'avais vu. 'It is a different movie from $X_{\text {pronoun(deictic) }}$ that I had watched.'

(8)' Ces films sont différents de $X_{\text {reciprocal. }}$ 'These movies are different from $\mathrm{X}_{\text {reciprocal.' }}$

(9)' J'ai vu des films différents de $X_{\text {reciprocal }}$ pendant les vacances. 'I watched different movies from $X_{\text {reciprocal }}$ during the holidays.'

(10)' Les critiques ont vu des films différents de $X_{\text {reciprocal. }}$ 'The critics watched different movies from $\mathrm{X}_{\text {reciprocal.' }}$

(11)' Par rapport à la semaine dernière, chaque enfant est différent de $\mathrm{X}_{\text {reflexive }}$ aujourd'hui.

'As compared to last week, each child is different from Xreflexive today.'

As for (4)-(5), they contain partially elided comparative clauses that resemble regular comparative clauses except that they involve individuals instead of degrees.

(4)' Paul a vu un film différent de [cp wh-film Marie a vu wh-film]. 'Paul watched a different movie than [cP h-movie Marie watched wh-movie].

(5)' J'ai regardé un film différent de [cp wh-film j'ai regardé wh-film hier].

'I watched a different movie than [cP wh-movie I watched wh-movie yesterday].'

Finally, (12)-(13) include fully elided comparative clauses that contain silent underspecified DPs.

(12)' Chaque critique a vu un film différent de [cp h-film $X_{\text {reciprocal }}$ wu-film]. 
'Each critic watched a different movie than [cP wh-movie $X_{\text {reciprocal watched wh- }}$ movie].'

(13)' Paul et Claire ont vu un film différent de [cP wh-film $X_{\text {reciprocal }}$ ont vu wh-film].

'Paul and Claire watched a different movie than [cP Wh-movie].'

The analysis of each case will be explained in more detail in section 2 for French différent. I will start with the cases where the standard is projected as a DP, explicit or silent (section 2.1.) and then examine those where the standard is projected as a CP (section 2.2.); in particular, it will be shown how island facts support the hypothesis of the presence of elided comparative clauses. Then in section 3, we will see how this analysis can extend to the cases of French même ('same') and autre ('other'). Finally, we will examine further issues (section 4) and briefly compare the present analysis with previous ones (section 5).

\section{Différent}

I assume that under all constructions, différent is a relational adjective that combines with two individuals; this is transparent in (1)'.

(1)' Lucie est différente de Claire.

'Lucie is different from Claire.'

Note that in this paper, I am not specifically interested in what it means to consider two entities as different, but in the distribution of différent. Based on Alrenga (2007), I will simply assume that difference and similarity are measured in terms of shared or distinguishing properties. ${ }^{2}$ One way to implement this idea is as follows ( $C$ is a set of contextually relevant properties $\mathrm{P}$ ):

$$
\text { 【différent }=\lambda x \cdot \lambda y . \exists P \in C, P(x)=1 \text { and } \mathrm{P}(\mathrm{y})=0
$$

My hypothesis is that the variety of constructions involving différent does not come from the existence of several lexical entries for différent, but derives from the various forms that the two elements of comparison take. In particular, we will see that the standard can project as a DP (section 2.1.) or a CP (section 2.2.).

\footnotetext{
2 As noted by a reviewer, the following examples show that différent does not only care about the nonidentity of objects (or types), but also about distinguishing properties.

(i) When it comes to likes and dislikes, Lucie is the same as Claire. With respect to desires, however, Lucie is completely different from Claire.

(ii) Lucie is simultaneously the same as and different from Claire, though with respect to distinct properties.
} 


\subsection{Standard as DP}

\subsubsection{Standard as explicit DP (case noted 'from DP')}

In (1)', both the compared element and the standard are full DPs (i.e. Lucie, Claire). As is common with relational terms (cf. (15)), a preposition (here de 'from') links différent and the standard.

(15) Lucie est proche de Claire.

'Lucie is close to Claire.'

Moreover, différent is predicative in (1)' but can also be attributive and occur within the DP denoting the compared element just like other relational terms (e.g. voisin 'neighbor' in (16)).

(2) J'ai vu un film différent de ce film-là.

'I watched a movie different from this one.'

(16) J'ai visité une ville voisine de cette ville-là.

'I visited a town nearby this one.'

In that case, I simply assume that différent is to be analyzed as a reduced relative clause (cf. Cinque 2010) and (2) basically corresponds to I watched a movie that is different from this one. Nothing hinges on this particular assumption: any account of (16) can simply extend to (2).

(3) is similar to (2) except that the standard includes a relative clause headed by $c e$ 'this, that'.

(3) Paul a vu un film différent de ce que proposait Marie. 'Paul watched a different movie than what Marie proposed.'

Note that we find all three cases not only with relational terms as shown above, but also with regular comparatives as exemplified below.

(17) Lucie est plus bronzée que Claire.

'Lucie is more tanned than Claire.'

(18) J'ai vu un film plus intéressant que ce film-là.

'I watched a more interesting movie than this one.'

(19) Paul a vu un film plus intéressant que ce que proposait Marie.

'Paul watched a more interesting movie than what Marie proposed.' 
Thus différent resembles both relational adjectives and comparatives. As a matter of fact, it can combine with two kinds of linker: de ('of, from'), which is often used with relational adjectives, and que ('than, that'), which is the linker used with comparatives; the latter option (cf. (3)" below) is more colloquial and is not used by all speakers of French. In the rest of the paper, we will simply use de with différent for simplicity.

(3)" \% Paul a vu un film différent que ce que proposait Marie.

'Paul watched a different movie than what Marie proposed.'

\subsubsection{Standard as implicit DP (case noted 'from X')}

Furthermore, the DP complement of différent can be implicit and underspecified as is the case with comparatives and relational terms. Depending on the context, this yields a range of different interpretations.

Interpretation of the implicit standard as a pronoun (noted 'from $X_{\text {pronoun') }}$

First, so-called external readings such as (6)' and (7)' can be accounted for if we suppose that the silent standard is interpreted as an anaphoric or deictic pronoun.

(6)' Lucie est allée voir Frida hier. Moi, j'ai vu un film différent-de- $X_{\text {pronoun(anaphoric). }}$ 'Lucie watched Frida yesterday. As for me, I watched a different movie-from X pronoun(anaphoric).'

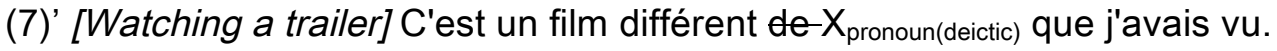
'It is a different from $X_{\text {pronoun(deictic) }}$ movie that I had watched.'

In (6)', différent compares the movie that the speaker watched with Frida, a movie mentioned in the previous sentence: Frida is a sentence-external element, which appears in the preceding discourse. In (7)', the movie that the speaker had watched is contrasted with a movie represented in a trailer, as mentioned in the context: the element of comparison is here deictically referred to. In other words, the reference of the standard is determined by the discourse in (6)' and the extralinguistic context in (7)': the implicit element is thus interpreted as an anaphoric pronoun and a deictic pronoun respectively.

No specific mechanism needs to be stipulated to account for that since the same holds with relational terms (cf. voisin 'neighbor, nearby' in (20)) and comparatives (cf. plus récent 'more recent' in (21)).

(20) a. Lucie est allée visiter Orléans hier. Moi, j'ai visité une ville voisine. 'Lucie visited Orléans yesterday. As for me, I visited a nearby town.' b. [Visiting Orléans] Moi je préfèrerais aller visiter une ville voisine. 
'I would prefer to visit a nearby town.'

(21) a. Lucie est allée voir Frida hier. Moi, j'ai vu un film plus récent.

'Lucie watched Frida yesterday. As for me, I watched a more recent movie.'

b. [Watching a trailer] C'est un film plus récent que j'avais vu.

'It is a more recent movie that I had watched.'

Interpretation of the implicit standard as a reflexive (noted 'from $X_{\text {reflexive') }}$

In particular situations like (11)', the silent standard can be interpreted as a reflexive.

(11)' Par rapport à la semaine dernière, chaque enfant est différent de $X_{\text {reflexive }}$ aujourd'hui.

'As compared to last week, each child is different from $\mathrm{X}_{\text {reflexive }}$ today.'

(11)' means that each child is different from herself today, i.e. from the way she was last week.

Again, the same is attested with relational terms like identique 'identical' in (22) or voisin 'neighbor' in (23), and with comparatives in specific contexts like (24). ${ }^{3}$

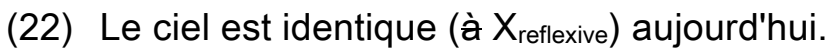

'The sky is identical (

(23) (Context: A couple owns two apartments that are next to each other)

Ils sont voisins (de $\mathrm{X}_{\text {reflexive }}$ )!

'They are neighbors ( $\Theta$ f $\left.\mathrm{X}_{\text {reflexive }}\right)$ !'

(24) a. Par rapport à hier, cette robe a l'air plus/moins élégante (que $X_{\text {reflexive) }}$ aujourd'hui.

'As compared to yesterday, this dress looks more/less elegant (than $\mathrm{X}_{\text {reflexive) }}$ today.'

b. Par rapport à hier, cette robe n'a pas l'air aussi élégante (que $\mathrm{X}_{\text {reflexive) }}$ aujourd'hui.

'As compared to yesterday, this dress does not look as elegant (as $\mathrm{X}_{\text {reflexive) }}$ today.'

Interpretation of the implicit standard as a reciprocal (noted 'from $X_{\text {reciprocal') }}$

Similarly, a reciprocal interpretation can obtain whether différent is predicative as in (8)' or attributive as in (9)':

\footnotetext{
${ }^{3}$ An overt reflexive makes the sentence degraded in all these cases - relational terms, comparatives and sidi terms. This is an independent issue, which is not specific to sidi terms (see footnote 6).
} 
(8)' Ces films sont différents de $X_{\text {reciprocal. }}$

'These movies are different from $\mathrm{X}_{\text {reciprocal.' }}$

(9)' J'ai vu des films différents de $X_{\text {reciprocal }}$ pendant les vacances.

'I watched different movies from $X_{\text {reciprocal }}$ during the holidays.'

This is again comparable to what we find with relational terms like similaire 'similar' in (25), voisin 'neighbor' in (26), or ennemi 'enemy' in (27).

(25) a. J'ai acheté trois robes similaires.

'I bought three similar dresses.'

b. Ces trois robes sont similaires (l'une à l'autre).

'These three dresses are similar (to each other).'

(26) a. J'ai visité des villes voisines.

'I visited nearby cities.'

b. Ces villes sont voisines (l'une de l'autre).

'These cities are nearby (each other).'

(27) a. Il s'agit de deux pays ennemis.

'These are two enemy countries.'

b. Ces deux pays sont ennemis (l'un de l'autre).

'These two countries are enemies (of each other).'

\section{More on the underspecification of the silent standard}

The fact that sidi terms are similar to relational terms in licensing the interpretation of the implicit argument as a pronoun, a reflexive or a reciprocal is crucial: it means that the analysis of sidi terms does not require any ad hoc mechanism, but we simply need to suppose that what happens with any relational term applies to sidi terms. In particular, I hypothesize that the implicit argument of relational terms or sidi terms is underspecified and the specific interpretation is constrained pragmatically. Thus, these different interpretations correspond to the same configuration and all interpretations (as a pronoun, a reflexive, a reciprocal or even a vaguer interpretation that is neither strongly reciprocal nor strongly reflexive) are in principle possible, but pragmatics will usually eliminate at least some of them based on salience and plausibility.

To illustrate the kind of underspecification I am appealing to, consider constructions with the reflexive clitic se in French. The first sentence below presents various interpretations:

(28) a. Les enfants se regardent.

'The children are looking at each other/themselves.'

b. Les enfants se jalousent. 
'The children are jealous of each other/themselves.'

If we suppose that a mirror is present in the context, the first sentence is compatible with a situation where each child is looking at himself, or all children are looking at themselves in the mirror (reflexive interpretation, distributive or not). But it can also be uttered in a situation where each child is looking at all the others (a strict reciprocal interpretation). Moreover, the sentence can express a mix of both situations: some children are looking at themselves, others are looking at other children (vague interpretation). It can even receive a vaguer interpretation where some children do not do anything (provided that most of them are looking at each other/themselves) or/and some of them are both looking at themselves and at some other children, etc... In other words, it has a very vague meaning paraphrasable as: "the children are looking at the children", which is deemed to be true in reciprocal, distributive reflexive, and all sorts of other intermediate situations. Note that this is sensitive to the choice of verb as shown by (28)b with the verb jalouser ('be jealous of'). In this sentence a reflexive interpretation, while not incompatible with the lexical meaning of the verb (one can be jealous of oneself, e.g. one former self), is very difficult to get if it is not made explicit.

Here, I apply the underspecification that we observe with the French clitic se to the silent complement of both relational terms and sidi terms. This underspecified pronoun gets its reference in various ways constrained by pragmatics yielding the reflexive, reciprocal and vague interpretations.

To be more precise, let's for instance examine the following sentence:

(29) J'ai vu vingt films différents pendant les vacances.

'I watched twenty different movies during the holidays.'

In principle, the silent complement of différent, that I hypothesize to be underspecified, can be interpreted in several ways: if there was a salient movie in the context, it could be interpreted as a pronoun referring to this movie (external reading) or have an external reading mimicking a reflexive interpretation if twenty movies were previously introduced all in color, and the sentence is talking about these same movies but all in black and white (so the movies are different from themselves); without any context and given that the DP containing différent is plural, it can easily be interpreted as a reciprocal; a reflexive reading (e.g. I watched twenty movies globally different from themselves, or each different from itself) seems hardly accessible much the same way that such interpretation is hardly accessible with se and the verb jalouser above because one is typically not jealous or different from oneself; finally, we could imagine that the interpretation is vaguer, neither strictly reciprocal nor strictly reflexive, but some movies are different from others and some movies are different from themselves (e.g. the same movie is in the list, once in color and once in black and white). In this very sentence, these four interpretations are not available due to pragmatic constraints (salience and 
plausibility) but we have seen examples of all four interpretations. Note finally that this behavior of different parallels that of the relational noun ennemi 'enemy' in (27): while it is possible in principle to be one's own enemy, it is unusual and a reflexive interpretation of (27) is hardly accessible (except by making it explicit).

\section{Comparison with comparatives}

We observed that comparatives can also be complemented by silent elements that can be interpreted as anaphoric or deictic pronouns in (21) and reflexives in particular situations like (24):

(21) a. Lucie est allée voir Frida hier. Moi, j'ai vu un film plus récent. 'Lucie watched Frida yesterday. As for me, I watched a more recent movie.'

b. [Watching a trailer] C'est un film plus récent que j'avais vu. 'It is a more recent movie that I had watched.'

(24) a. Aujourd'hui, cette robe a l'air plus/moins élégante. 'Today, this dress looks more/less elegant.'

b. Aujourd'hui, cette robe n'a pas l'air aussi élégante. 'Today, this dress does not look as elegant.'

Reflexive interpretations are possible only if the same elements are compared at different times (the presence of aujourd'hui 'today' licenses this interpretation in (24)). Reciprocal interpretations are however unavailable: whether we deal with comparatives of superiority/inferiority as in (30) or equatives as in (31), the silent complement can only be interpreted as a pronoun, not as a reciprocal.

(30) a. \# reciprocal J'ai mis des robes plus/moins élégantes pendant les vacances.

'I put on more/less elegant dresses during the holidays.'

b. \# reciprocal Ces robes sont plus/moins élégantes.

'These dresses are more/less elegant.'

(31) a. ??reciprocal J'ai mis des robes aussi élégantes pendant les vacances.

'I put on dresses as elegant during the holidays.'

b. ? reciprocal Ces robes sont aussi élégantes.

'These dresses are as elegant.'

This difference between comparatives and sidi or relational terms is due to the meaning of comparatives. Reciprocals require a symmetrical meaning, while inferiority and superiority comparatives (cf. (30)) are obviously not symmetrical. Furthermore, standard semantic accounts of equatives ascribe them an 'at least' meaning, deriving an 'exactly' reading when necessary via scalar implicature (cf. Rett: 2010 for discussion). This means that equatives are not inherently symmetrical, but only get a symmetrical 
meaning through implicature. I propose that this accounts for the intermediate judgment of sentence-internal readings of equatives (cf. (31)). Similarly, the meaning of comparatives makes reflexive interpretations hardly accessible except in contexts like (24) where time introduces an order and the same element can be compared to itself at different times.

Special case of reciprocal interpretation

Consider again the following sentence:

(10)' Les critiques ont vu des films différents.

'The critics watched different movies.'

Just like (9)', it can mean that the critics watched different types of movies, i.e. movies that are different from each other. The silent standard is here interpreted as a reciprocal.

(9)' J'ai vu des films différents de $X_{\text {reciprocal }}$ pendant les vacances.

'I watched different from $X_{\text {reciprocal }}$ movies during the holidays.'

But (10)' exhibits another salient interpretation: each critic (or each subgroup of critics) watched a movie different from the movies watched by the other critics (or subgroups of critics). This interpretation has often been considered as a different reading. But here following Beck's (2000) analysis of German verschieden ('different'), I suppose that the apparent difference between this interpretation (each critic watched different movies than the other critics) and the previous one (each critic watched movies that are different from each other) is pragmatic: the difference in interpretation comes from the availability of different covers (a cover $\mathrm{C}$ of a set $\mathrm{S}$ is a set of subsets of $\mathrm{S}$ such that every member of $S$ belongs to some set in $C$ and $\varnothing$ is not in C; see Schwarzschild: 1996 for more details). Indeed several possible covers of the movies in question can be pragmatically determined based on salience: depending on what is pertinent in the context, the movies can be divided into different kinds of subparts (the classification can be based on different criteria, e.g. the type of movies, the producer, the date, the length, the people who watch them...etc). For example in (10)', if the salient cover divides movies according to their kinds (e.g. comedies and cartoons), this will give rise to the first interpretation I mentioned. The second interpretation obtains when the partition is made along the dimension of the viewers \{movies watched by a subgroup of critics, movies watched by another subgroup...\}. According to Beck (2000: 113-125) based on Schwarzschild (1996), a free variable ranging over covers appears at LF whenever there is $a^{*}$ (distributive) operator: the free variable Cov occurs in the sister of the * operator and it is interpreted intersectively with a predicate. ${ }^{4}$

\footnotetext{
4 This explains why the presence of différent - a predicate - is crucial to activate the cover-based interpretation: Cov needs to occur in the sister of a distributive operator, which has to scope over a predicate. This is why as noted by an anonymous reviewer, (10)' is a reasonable answer to (iii), but (iv) is
} 
(10)" Les critiques ont vu des films [ [ [Cov différents [de X]]].

'The critics watched movies [* [Cov different [from X]]].'

This interpretation is even more salient in the presence of a coordination that makes the partition more explicit:

(32) Paul et Claire ont vu des films différents.

'Paul and Claire watched different movies.'

The following interpretation is here salient: the movie that Paul watched is different from the movie that Claire watched.

This analysis correctly predicts that vague interpretations are possible (if the relevant covers are available). ${ }^{5}$ Thus (10)' does not constrain a strict distribution of the movies across each critic: it may be the case that some critics watched the same movie; it just means that the cover is slightly different in this case (the subgroups of critics can be singleton sets or not).

As mentioned by Beck (2000: 126-127), the pragmatic account of this reading correctly predicts (in German in (33) and in French in (34)) that it is also possible when the two DPs are separated by a scope island since it is not syntactically, but pragmatically driven. The importance of this consequence will be made clearer later on in the article.

(33) a. Die Bücher, die Franck und Bärbel mögen, sind verschieden. (Beck, 2000: 126)

'The books that Frank and Bärbel like are different.'

b. Ottilie und Maria haben Bücher gelesen, die zu verschiedenen Schlüssen kamen. (Beck, 2000: 127)

'Ottilie and Maria read books that came to different conclusions.'

(34) a. Les films que Paul et Claire ont vus sont différents.

'The movies that Paul and Claire watched are different.'

b. Paul et Claire ont vu des films qui menaient à des conclusions différentes.

not: there is no predicate in (iv) that can license the presence of a distributive operator and a cover variable which would distribute over movies.

(iii) Pourquoi est-ce qu'aucun film n'a été commenté par deux critiques ou plus ?

'Why was no movie written about by 2 or more critics?'

(iv) Les critiques ont vu des films. 'The critics saw movies.'

${ }^{5}$ As mentioned by Carlson (1987) and Beck (2000), there is even one case where différent seems to be semantically vacuous: this is when the salient cover divides the relevant plural into singularities without appealing to salient criteria of division other than the fact of being distinct objects.

(v) John went to five different plays. (from Beck, 2000: 125)

Under one interpretation, the five plays are only different in that there are distinct plays. I suspect that the role played by different here relies on information structure: by redundancy, it emphasizes the fact that there are several plays at stake, not just one. 
'Paul and Claire watched movies that came to different conclusions.'

To sum up, several interpretations arise depending on the context when the standard is projected as a DP because it can be implicit and underspecified. Here is a summary of the main cases.

\begin{tabular}{|l|l|}
\hline \multicolumn{1}{|c|}{ Case } & \multicolumn{1}{c|}{ Example } \\
\hline $\begin{array}{l}\text { Standard as overt DP } \\
\text { ('from DP') }\end{array}$ & $\begin{array}{r}\text { (1)' Lucie est différente de Claire. } \\
\text { 'Lucie is different from Claire.' } \\
\text { (2) J'ai vu un film différent de ce film-là. } \\
\text { 'I watched a movie different from this one.' } \\
\text { (3) Paul a vu un film différent de ce que proposait Marie. } \\
\text { 'Paul watched a different movie than what Marie proposed.' }\end{array}$ \\
\hline $\begin{array}{l}\text { Standard as implicit DP } \\
\text { ('from X') } \\
\text { X is underspecified and } \\
\text { can in particular be } \\
\text { interpreted as a } \\
\text { pronoun, a reflexive or a } \\
\text { reciprocal. }\end{array}$ & $\begin{array}{r}\text { (6)' Lucie est allée voir Frida hier. Moi, j'ai vu un film différent-de-X. } \\
\text { 'Lucie went and watched Frida yesterday. As for me, I watched a } \\
\text { (7)' 'Watching a trailer] C'est un film différent de X que j'avais vu. } \\
\text { 'It is a different from X movie that I had watched.' } \\
\text { (8)' 'Thes films sont différents de X. } \\
\text { (9)' J'ai vu des films différents de X pendant les vacances. } \\
\text { 'I watched different movies from X during the holidays.' } \\
\text { (10)' Les critiques ont vu des films différents de X. } \\
\text { 'The critics watched different movies.' } \\
\text { (11)' Par rapport à la semaine dernière, chaque enfant est différent } \\
\text { de X aujourd'hui. } \\
\text { 'As compared to last week, each child is different from X today.' }\end{array}$ \\
\hline
\end{tabular}

Table 1: Standard as DP

\subsection{Standard as CP}

A second set of interpretations arises when the standard is projected as a CP: I hypothesize that like regular comparatives, sidi terms can be complemented by a comparative clause; as this section will show, this hypothesis is based on similarities between comparatives and sidi terms and on island facts that argue for the presence of a silent clause. Different cases obtain depending on how much the comparative clause is elided and how the silent elements are interpreted.

\subsubsection{Standard as partially elided CP (case noted 'than [cp remnant]')}

First, a fully overt comparative clause (except for the compared element) is not acceptable with sidi terms (cf. (35)), just as in the case of any comparative in French (cf. (36)) unlike English.

(35) *Paul a vu un film différent de Marie a vu. 
'Paul watched a different movie than Marie watched.'

(36) *Paul a vu un film plus intéressant que Marie a vu.

'Paul watched a more interesting movie than Marie watched.'

The comparative clause has to be at least partially elided. The following examples (cf. (4)'-(5)') contain a reduced comparative clause complementing différent through the preposition de or que 'than' as is the case with regular comparatives (cf. (37)-(38)).

(4)' Paul a vu un film différent de Marie.

'Paul watched a different movie than Marie.'

(5)' J'ai regardé un film différent d'hier.

'I watched a different movie than yesterday.'

(37) Paul a vu un film plus intéressant que Marie.

'Paul watched a more interesting movie than Marie.'

(38) J'ai regardé un film plus intéressant qu'hier.

'I watched a more interesting movie than yesterday.'

Note that the complement of différent de 'different than' seems to be a DP as in previous cases like (2)'.

(2) J'ai vu un film différent de ce film-là.

'I watched a movie different from this one.'

But the complement DP in (2) directly corresponds to the standard (ce film-là 'this movie') as opposed to (4)' where the movie is not directly compared to Marie, but to the movie watched by Marie. Moreover in (5)', the phrase appearing after différent de, namely hier 'yesterday', does not denote an individual; the movie cannot be compared to yesterday, but to the movie that I watched yesterday. Furthermore, multiple phrases can occur after différent que/de as shown in (39).

(39) Paul a vu un film différent de Marie hier.

'Paul watched a different movie than Marie yesterday.'

That's why I hypothesize that examples such as (4)' or (5)' are reduced clauses (we will discuss in section 5.1.1 whether examples like (2) can also be reduced to such cases), just as has been proposed for regular comparatives such as (37) or (38).

The only difference between différent and regular comparatives comes from the fact that différent involves a comparison between individuals, not degrees. Accordingly, I assume 
that the comparative clause does not denote a maximal degree (cf. a.o. Kennedy 1999), but an individual: just like a free relative clause, the comparative clause corresponds to a definite description (cf. a.o. Caponigro: 2004 for more detail about free relatives). Otherwise, I simply assume that the analysis of regular comparatives can be applied to these cases.

More precisely, I suppose like most analyses (cf. a.o. Hankamer 1973, Chomsky 1977, Heim 2000, Kennedy 2002) that comparative clauses involve wh-movement of the compared element in the Specifier of CP.

(4)' Paul a vu un film différent de [cp wh-film Marie a vuwh-film]. 'Paul watched a different movie than [cp wh-movie Marie watched wh-movie].'

(5)' J'ai regardé un film différent de [cP h-film j'airegardé wh-film hier]. 'I watched a different movie than [cP movie I watched wh-movie yesterday].'

Moreover, the elided part of the comparative clause (e.g. the VP in (4)') is retrieved through identity of the antecedent (e.g. the matrix VP in (4)') as in any case of ellipsis. Since the VP antecedent seems to contain the elided VP ([vP watched a different movie than Marie [vp watched ...]]), we need to apply Quantifier Raising (QR) to avoid infinite regression (cf. a.o. Kennedy 1997) as illustrated below: antecedent containment is standardly resolved via movement and copying/deletion of identical material from the matrix clause in the ellipsis site (henceforth ACD, for Antecedent Contained Deletion). Note that I here suppose that the trace contains the content of the NP, but any other alternative analysis could be applied here since this issue is independent of the present analysis.

(4)' [un film différent de [cr wh-film Marie avuwh-film] Paul a vu film.

'a different movie than [cP wh-movie Marie watched wh-movie] Paul watched movie.'

(5)' [un film différent de [CP wh-film j'ai regardé wh-film hier]] j'ai regardé film.

'[a different movie than [cP wh-movie I watched wh-movie yesterday]] I watched movie.'

Also, the remnant (e.g. Marie in (4)') needs to move to a clause-external (or clauseperipheral) position concomitant with clausal ellipsis. The necessity of this movement for ellipsis resolution is clearer when the remnant is in an object position as in (40).

(40) A more important person met Pierre than Marie.

To guarantee identity between the antecedent and the ellipsis (a person met $x$ ), Pierre and Marie need to be replaced by a variable: I adopt the hypothesis (cf. a.o. Heim 1997) 
that this happens through focus movement of Pierre and Marie. This is represented below in a simplified way, but note that for simplicity, I will not represent this movement in most examples of the paper.

(40)' [Foc Pierre] [a more important person [a person met x]] than [[Foc Marie] [a person-met $\mathrm{x}]]$.

Furthermore, I assume that as in the previous cases (cf. (2)), different should be analyzed as a reduced relative clause (a different movie (from) amounts to a movie that is different (from)). Therefore, it combines as usual with two individuals in those examples: the first one is the DP combining with this reduced relative clause (un film 'a movie'); the second one is the comparative clause interpreted as a definite description like a free relative clause.

\subsubsection{Standard as fully elided CP (case noted 'than [cP X]')}

Now, we have all the ingredients to account for the so-called sentence-internal readings salient in (12)' or (13)', which have received a lot of attention in the literature.

(12)' Chaque critique a vu un film différent.

'Each critic watched a different movie.'

(13)' Paul et Claire ont vu un film différent.

'Paul and Claire watched a different movie.'

We simply need to suppose that (12)' and (13)' have the same structure as (4)' except that the remnant (Marie in (4)') is the same underspecified element (noted as X) as that mentioned previously in section 2.1.2, which can be interpreted as a pronoun, a reflexive or a reciprocal depending on the pragmatic conditions.

(12)' Chaque critique a vu un film différent de [cP 'Each critic watched a different movie than [cp wh-movie X watched wh-movie].'

(13)' Paul et Claire ont vu un film différent de [cp wh-film $X$ ont vu wh-film].

'Paul and Claire watched a different movie than [CP wh-movie $X$ watched whmovie\}.'

Concentrating first on (13)', the underspecified element can indeed be interpreted in different ways:

(41) a. Lucie est allée voir Frida. Paul et Claire ont vu un film différent de [cP h-film

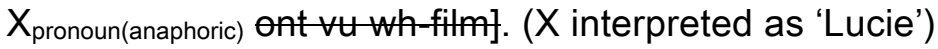

'Lucie watched Frida. Paul and Claire watched a different movie than [CP whmovie $X_{\text {pronoun(anaphoric) watched wh-movie].' }}$ 
b. Cette semaine, Paul et Claire ont vu un film différent de [cP h-film $X_{\text {reflexive }}$ ont vu wh-film]. (X interpreted as 'themselves')

'This week, Paul and Claire watched a different movie than [cP wh-movie $X_{\text {reflexive watched wh-movie]. }}$

c. Paul et Claire ont vu un film différent de [cP wh-film $X_{\text {reciprocal }}$ ent vu wh-film]. (X interpreted as 'each other')

'Paul and Claire watched a different movie than [cP wh-movie $X_{\text {reciprocal }}$ watched wh-movie].

In a context like (41)a where someone else watched a movie in the context, $X$ is preferably interpreted as a pronoun. In a situation like (41)b where Paul and Claire watched a movie at another time (e.g. last week), $X$ is easily interpreted as a reflexive: they watched a movie different from the movie that they themselves watched the previous week. Finally, the easiest interpretation is the reciprocal one as in (41)c: Paul and Claire watched a different movie than each other.

The same holds with (12)': it can mean that each critic watched a different movie than someone mentioned in the previous context (cf. (42)a), than he himself did at another occasion (cf. (42)b) ${ }^{6}$ or than every other critic did (cf. (42)c). ${ }^{7}$

(42) a. Lucie est allée voir Frida. Chaque critique a vu un film différent de [cp wh-film

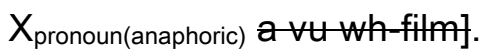

'Lucie watched Frida. Each critic watched a different movie than [cP wh-movie $X_{\text {pronoun(anaphoric) watched wh-movie].' }}$

b. Cette semaine, chaque critique a vu un film différent de [cP vuwh-film].

${ }^{6}$ The same sentence (under the reflexive interpretation) is not acceptable when the silent underspecified pronoun is replaced by an explicit element, i.e. a reflexive or a bound pronoun as in (vi)a, unless the whole comparative clause is made overt as in (vi)b:

(vi) a. *Cette semaine, [chaque critique]i a vu un film différent de lui-mêmei /luii (la semaine dernière).

'This week, [each critic]i watched a different movie than himselfi/himi (last week).'

b. Cette semaine, [chaque critique]i a vu un film différent de celui qu'ili a vu la semaine dernière).

'This week, [each critic]i watched a different movie than what hei watched last week.'

It is not clear exactly why this is so, but this problem is independent of the specific behavior of sidi terms since the same holds with regular comparatives:

(vii) a. ${ }^{*}$ Cette semaine, Pauli a vu un plus beau film que lui-mêmei/luii (la semaine dernière).

'This week, Pauli watched a more beautiful movie than himselfi/himi (last week).'

b. Cette semaine, Pauli a vu un plus beau film que celui qu'ili a vu la semaine dernière.

'This week, Pauli watched a more beautiful movie than hei watched last week.'

Note that it is known (cf. Partee 1989) that in general, implicit arguments behave differently from explicit elements.

7 Unlike the reflexive interpretation (cf. previous footnote), the reciprocal interpretation can be paraphrased with an explicit element, i.e. les autres 'the others':

(viii) Chaque critique a vu un film différent des autres.

'Each critic watched a different movie than the others.' 
'This week, each critic watched a different movie than [cP watched wh-movie].'

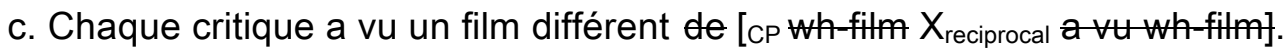

'Each critic watched a different movie than [cP wh-movie $X_{\text {reciprocal watched }}$ wh-movie\}.'

This variety of interpretations is independently attested with the overt plural pronoun ils ('they'), which is underspecified in the following sentences:

(43) a. Paul et Pierre ont dit qu'ils étaient malades.

'Paul and Pierre said that they were sick.'

b. (speaking of a group of students) Chacun a dit qu'ils étaient malades.

'Each one said that they were sick.'

Whether the antecedent is a conjunct (as in (43)a), or a quantifier (as in (43)b), the plural pronoun ils ('they') is vague and can be interpreted in different ways. For instance in (43)a, Paul may have said that some people salient in the context are sick, that he himself is sick, that both Pierre and himself are sick or that Pierre is sick; the same holds for Pierre (the only requirement - because of the plural - seems to be that both of them have been said to be sick). Similarly, (43)b requires that every student said something about the sickness of people, but he may have said that some salient people were sick, that he was sick himself, that all the (other) students were sick or only some of them (including himself or not).

Thus in particular, each sentence licences a strict reciprocal interpretation just as under the salient interpretation of (12)' and (13)' involving sidi terms. This is even clearer in the following sentences:

(44) a. Paul et Pierre espèrent qu'ils iront à leur enterrement. 'Paul and Pierre hope that they will come to their funeral.'

b. (speaking of a group of friends) Chacun espère qu'ils iront à son enterrement.

'Each one hopes that they will come to his funeral.'

Here, the pronoun ils ('they') can clearly be interpreted as a reciprocal, since one cannot go to one's own funeral: 8 (44)a can mean that Paul and Pierre each hope that the other will come to his funeral, and (44)b that each one hopes that the others will come to his funeral.

Distributivity of the licensor

The reciprocal interpretation is however subject to some constraints because it requires a plural object so that its members can be compared to each other: for instance in (12)'

\footnotetext{
8 If leur 'their' is interpreted as a reciprocal in (44)a, ils 'they' can be interpreted as a reflexive. The truth conditions are of course different.
} 
and (13)', several movies have to be compared to each other. Since the DP containing différent can be singular under this reading (cf. a.o. un film différent 'a different movie' in (12)' and (13)'), this means that it has to be interpreted within the scope of a distributive operator so that un film différent 'a different movie' can denote a potentially different movie for every choice of the critics distributed over. This obtains - as is standard with any indefinite - if it is outscoped by a quantificational or plural DP (henceforth, licensor) that is suitable.

Indeed, a non-quantificational singular licensor (underlined below) only licenses a pronominal or reflexive interpretation.

(45) Paul a vu un film différent.

'Paul watched a different movie.' (i.e. from some other movie, than someone else did, than he himself did at another time)

A quantificational DP can however yield a distributive interpretation of the indefinite containing différent if it c-commands it at LF (this holds for both reciprocal and reflexive interpretations). Indeed, the internal reading does not obtain when the licensor cannot QR and does not c-command différent at surface structure as is the case with some quantifiers like modified numerals (cf. a.o. Szabolcsi: 1997) such as plus de trois films 'more than three movies' as in (47)b. Thus (46) - where the licensor chaque film 'each movie' can QR - and (47)a - where the licensor plus de trois critiques 'more than three critics' c-commands différent at surface structure - contrast with (47)b where neither occurs.

(46) Un critique différent a vu chaque film. ${ }^{9}$ 'A different critic watched each movie.'

(47) a. Cette semaine, plus de trois critiques ont vu un film différent. 'This week, more than three critics watched a different movie.'

b. \# Un critique différent a vu plus de trois films.

'\# A different critic watched more than three movie.'

\footnotetext{
9 Unlike the case where différent occurs in a object DP (cf. footnote 7), this example - where it is contained within a subject - cannot be paraphrased using an explicit element:

(ix) *Un critique différent des autres (films) a vu chaque film.

'*A different critic than the other (movies) watched each movie.'

This problem is independent of sidi terms since the same contrasts are observed with regular comparatives: compare (x)a with (ix), (x)b with (viii) and (x)c with (46).

(x) a. *Un étudiant plus intelligent que cette équation a résolu ce problème.

'*A smarter student than this equation solved this problem.'

(intended meaning: a smarter student than the student that solved this equation solved this problem)

b. Cet étudiant a résolu un problème plus difficile que ce professeur.

'This student solved a harder problem than this teacher.'

c. Un étudiant plus intelligent a résolu chaque nouveau problème.

'A smarter student solved each new problem.'
} 
Concerning plural licensors, the requirement for them to license a distributive interpretation in French is that the licensor can easily be partitioned: ${ }^{10}$ this is so in the presence of tous 'all' (cf. (48)a), the conjunction et 'and' (cf. (48)b), or numerals (cf. (48)c).

(48) a. Tous les critiques ont vu un film différent.

'All the critics watched a different movie.'

b. Paul et Claire ont vu un film différent.

'Paul and Claire watched a different movie.'

c. Les trois critiques ont vu un film différent.

'The three critics watched a different movie.'

However, the reciprocal interpretation is harder to obtain if the licensor is a simple plural definite as in (49), unless the partition of the licensor is made explicit as in (50).

(49) ?reciprocal Les critiques ont vu un film différent.

'The critics watched a different movie.'

(50) a. Les quatre critiques n'ont pas les mêmes goûts, alors ils ont choisi de voir un film différent.

'The four critics do not have the same tastes, so they chose to watch a different movie.'

b. C'est normal que tu ne comprennes pas ce que je dis, on a vu un film différent!

'Of course you don't understand what I am saying, we saw a different movie!'

In (50)a, the simple plural ils 'they' referring to the critics licenses a reciprocal interpretation because the previous discourse specifies that there are four distinct critics. In (50)b, the simple plural on (colloquial equivalent to nous 'we') clearly composed of me 'me' and tu 'you' also licenses a reciprocal interpretation.

The difference between plain definite plurals and quantifiers or partitioned plurals in their capacity of licensing a reciprocal interpretation of différent is due to their different behavior with respect to distributivity. Below, we observe independent evidence showing that plural definites (in (51)) do not behave like quantifiers (in (52)-(53)), definites with numerals (in (54)) or coordinations (in (55)) with respect to distributivity: a continuation with a plural referring to the movies is not possible in (51), but it is in (52)(53), (54) and (55).

(51) a. *Les critiques ont vu un film. Ils ont tous duré plus de deux heures.

'The critics watched a movie. They all lasted more than two hours.'

\footnotetext{
10 See Laca and Tasmowski (2001) for a discussion on the relation between the distributivity of the licensor and the use of siditerms.
} 
b. *Les touristes ont interrogé un garde qui surveillait une salle de musée. Ils ont tous été serviables.

'The tourists asked questions to a guard who was watching over a room of the museum. They were all helpful.'

(52) a. Chaque critique a vu un film. Ils ont tous duré plus de deux heures.

'Each critic watched a movie. They all lasted more than two hours.'

b. Chaque touriste a interrogé un garde qui surveillait une salle de musée. Ils ont tous été serviables.

'Each tourist asked questions to a guard who was watching over a room of the museum. They were all helpful.'

(53) a. Tous les critiques ont vu un film. Ils ont tous duré plus de deux heures.

'All the critics watched a movie. They all lasted more than two hours.'

b. Tous les touristes ont interrogé un garde qui surveillait une salle de musée. Ils ont tous été serviables.

'The tourists asked questions to a guard who was watching over a room of the museum. They were all helpful.'

(54) a. Les huit critiques ont vu un film. Ils ont tous duré plus de deux heures.

'The eight critics watched a movie. They all lasted more than two hours.'

b. Les huit touristes ont interrogé un garde qui surveillait une salle de musée. Ils ont tous été serviables.

'The eight tourists asked questions to a guard who was watching over a room of the museum. They were all helpful.'

(55) a. Marie et Claire ont vu un film. Ils ont tous les deux duré plus de deux heures. 'Marie and Claire watched a movie. They both lasted more than two hours.'

b. Marie et Claire ont interrogé un garde qui surveillait une salle de musée. Ils ont tous les deux été serviables.

'Marie and Claire asked questions to a guard who was watching over a room of the museum. They were both helpful.'

Given that a plural continuation requires the preceding indefinite un film ('a movie') or un garde ('a guard') to be interpreted in the scope of a distributive operator, this shows that plural definites do not provide distributive operators in the same way as quantifiers, coordinations or plurals with numerals.

Note nevertheless that (51)a' does not imply that the critics watched the same movie. Also, a plural definite can combine with a distributive predicate as in (56).

(51)a'. Les critiques ont vu un film. 'The critics watched a movie.'

(56) Les critiques ont les yeux bleus. 'The critics have blue eyes.' 
This suggests that the possibility of being the subject of a distributive predicate as in (51)a' and (56) does not entail the possibility of being a distributive operator taking scope over an indefinite as shown by (51). ${ }^{11}$

The reciprocal interpretation is thus harder to obtain in (49) because the licensor - plural definite - does not easily license a distributive operator that can outscope an indefinite. In fact, this interpretation is impossible with collective licensors like la classe ('the class'):

(57) a. \#La classe a vu un film différent.

'The class watched a different movie.'

b. \#La classe a vu un film.

'The class watched a movie.'

(57)a cannot mean that each student of the class watched a different movie (than the others), because (57)b cannot be interpreted this way either: only one movie is involved as la classe 'the class' is collective and does not license a distributive operator.

Also, this distributivity issue makes the reciprocal interpretation unavailable with plural definites for a second reason: the underspecified pronoun that occurs in the comparative clause under the present analysis could hardly be interpreted as a reciprocal just like the plural pronoun in (58) when anteceded by a plural definite.

(58) a. ??Les étudiants ont dit qu'ils étaient malades.

'The students said that they were sick.'

Intended interpretation: each student said that the others were sick.

b. ??Ces amis d'enfance espèrent qu'ils iront à leur enterrement.

'These childhood friends hope that they will come to their funeral.'

Intended interpretation: each friend hopes that the others will come to his funeral.

In sum, singular différent can give rise to reciprocal interpretations only if the licensor provides a distributive operator: this is the case of quantifiers, coordinations, partitioned plurals, as opposed to plain plural definites and collectives. Thus the difference between singular and plural différent in (49) and (10)' in licensing the internal reciprocal interpretation comes down to the difference between plural definites and other licensors with respect to distributivity.

(49) ?reciprocal Les critiques ont vu un film différent.

'The critics watched a different movie.'

\footnotetext{
11 This is by itself an interesting issue that I cannot treat here. See Schwarzschild (1993) for the hypothesis that distributive interpretations of sentences with plural definite subjects do not derive from the presence of a silent distributive operator but differ from non-distributive interpretations only pragmatically. Also note that the absence of distributive operators with plural definites in the plain meaning is also implied by analyses that suppose a homogeneity presupposition for plural definites (a.o. Loebner: 1987) or obtain the universal reading of plural definites in upward entailing environments through an implicature (Magri: 2014).
} 


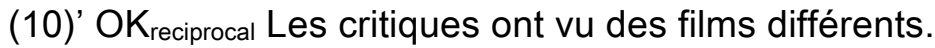

'The critics watched different movies.'

Unlike singular différent, plural différent can indeed be analyzed in terms of cover à la Beck (2000) as explained in section 2.1.2. This is why (49), which can only be constructed with a silent $\mathrm{CP}$ and is subject to the distributivity issue discussed above, contrasts with (10)', which can be analyzed as involving a DP complement: (10)' can mean that each critic watched a different movie than the other critics because the movies are denoted by a plural DP and can pragmatically be partitioned along the dimension of viewers.

(49) ? Les critiques ont vu un film différent de [cP h-film $X_{\text {reciprocal }}$ ent vu wh-film].

'The critics watched a different movie than [cp wh-movie $X_{\text {reciprocal watched wh- }}$ movie].'

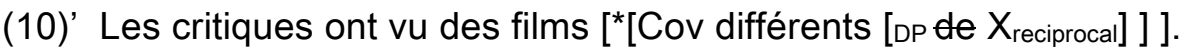

'The critics watched [ $\left[\right.$ Cov different movies [DP from $\left.\left.X_{\text {reciprocal }}\right]\right]$.'

Note that in English, the data are reported to be different (the following examples come from Brasoveanu, 2011: 4): not only does a simple plural as in (59)a preclude a reciprocal interpretation (i.e. the equivalent contrast between (49) and (10)' is stronger), but also numerals as in (59)b, all as in (59)c and conjuncts as in (59)d.

(59) a. The boys recited a different poem. (sentence-external only)

b. Two / The two boys recited a different poem. (sentence-external only)

c. All (of) the boys recited a different poem. (sentence-external only)

d. Linus and Mary recited a different poem. (sentence-external only)

This led some researchers (e.g. Brasoveanu 2011) to posit two different lexical entries for singular different and plural different. This difference between French and English would require further investigation to understand to which extent the present analysis could be applied to English. ${ }^{12}$ Note nevertheless that an anonymous reviewer found the reciprocal interpretation to be readily available in (59)c, though not in the other examples in (59), which suggests that there appears to be some speaker variation here. I suspect that such variation could be due to differences - between French and English and/or among speakers - with respect to the licensing of silent distributive operators. ${ }^{13}$

\footnotetext{
12 As noted by Brasoveanu (2011), Dotlačil (2010: 219-222) observes that sentence-internal readings under plural definites or DP conjunctions are available for one of the counterparts of singular different in Dutch and Czech. See Dotlačil (2010) for more detail about the relation between distributivity and licensing of same, different and other in Dutch.

13 For instance, the fact that all the boys, the two boys and Linus and Mary pattern with the boys, not with every boy (according to Brasoveanu 2011) as far as the licensing of the internal reciprocal interpretation of different is concerned, may be related to the fact that English has two distributive quantifiers each (strongly
} 
A further question that arises concerning licensors is whether a quantified licensor (e.g. chaque critique 'each critic' below) binds the silent underspecified pronoun (X) under the reflexive interpretation.

(12)' Chaque critique a vu un film différent de [cp fh-film $X$ a vu wh-film]. 'Each critic watched a different movie than [cP wh-movie X watched wh-movie].'

Indeed, the reflexive interpretation seems to be paraphrasable by a bound pronoun:

(60) Cette semaine, [chaque critique] $]_{k}$ a vu un film différent de celui qu'il $\underline{k}_{k}$ a vu la semaine dernière.

'This week, [each critic] $]_{k}$ watched a different movie than $\underline{\underline{h}}_{\mathrm{k}}$ saw last week.'

This question is hard to answer for the following reasons.

First, a positive answer would predict that the licensor must c-command the elided comparative clause at LF. But this is tricky to test as we have seen that a quantificational licensor must anyway outscope the DP containing différent for a distributive interpretation to arise, which is required under the reciprocal and reflexive interpretations: if the licensor cannot move, the internal interpretation is anyway unavailable. Therefore, we cannot prove that binding is mandatory by using cases where the licensor does not c-command the sidi term (or cannot move to c-command it), which would preclude binding, because the movement of the licensor is anyway required for another reason.

Furthermore, we can obtain the right interpretation when there is no possible binding, i.e. a plural pronoun that is not bound by a quantifier like each can be interpreted reflexively or reciprocally. Consider the following sentences:

(61) Le film que chaque critique a vu leur a plu.

'The movie that each critic watched pleased them.'

(62) (Speaking of a group of friends) La certitude que chacun mourra un jour les attriste.

'The certainty that each one will die some day makes them sad.'

(61) is an example of sentence where a plural pronoun (leur 'them') licenses a reflexive distributive interpretation even if it is not bound by each (each critic does not c-command them and cannot QR since it occurs in an island): for each critic, the movie he saw pleases him. Sentence (62) illustrates that les 'them' also licenses a reciprocal

distributive) and every (weakly distributive), while French only has one (chaque 'each'). The existence of weakly distributive every may preclude - by competition - all the boys, the two boys and Linus and Mary from licensing a silent distributive operator. 
distributive interpretation if it is not bound by each (chacun 'each one' does not ccommand les them' and occurs in an island): it means that for each friend, his future death makes his friends sad; this is possible in a context where one's own death does not make one sad.

Can Weak Crossover (WCO) help us decide? If the silent underspecified element present in the comparative clause is bound by the quantified licensor, this seems to predict WCO effects when the licensor needs to cross over the sidi term to c-command it. In other words, WCO seems to be an argument that there cannot be binding in such cases but the right interpretation obtains without binding as in (61). Note that according to Brasoveanu (2011: 137-138), WCO is a reason to analyse singular different and pronominal items in a different way. ${ }^{14}$

To be more precise, consider again the relevant example:

(46) Un critique différent a vu chaque film.

'A different critic watched each movie.'

If the binding of the underspecified element $X$ is mandatory, the licensor must QR to be able to bind this element, which occurs in a reduced comparative clause as illustrated below.

(63) [Chaque film $]_{1}$ Un critique différent de [cP h-critique wh-critique a vu- $\mathrm{X}_{1}$ ] a vu [ehaque film] 1 .

'[Each movie $]_{1} \mathrm{~A}$ different critic than [cP wh-critic wh-critic watched $\mathrm{X}_{1}$ ] watched [each movie] $]_{1}$ '

This configuration seems to correspond to a WCO configuration: to bind X, the quantifier chaque film 'each movie' crosses over it by covert movement $(\mathrm{QR})$, just as in standard cases of WCO such as '?hisi mother loves [each boy]i'. Yet, the sentence is grammatical, which would suggest that there is no binding.

Nevertheless, two observations are in order here.

First, the silent element is embedded into a (reduced) comparative clause, and WCO effects tend to be obviated when the bound pronoun is deeply embedded in a clause (as noted in Fox 2000: footnote 23, and Sportiche: 2005). This is illustrated in (64) showing that WCO effects are drastically reduced if the pronoun is embedded in a clause inside the subject: (64)b where the pronoun le is embedded in a relative clause sounds much better than (64)a that contains a possessive pronoun.

\footnotetext{
14 Brasoveanu (2011) predicts the presence of WCO effects with pronouns because their anaphoric potential is analyzed in terms of dref (i.e. discourse referent in dynamic semantics) coindexation. However, he predicts the absence of WCO effects with sentence-internal singular different because no dref coindexation is established between different and the distributive quantifier licensing it: singular different is always coindexed with the immediately preceding indefinite article, so the WCO constraint does not apply.
} 


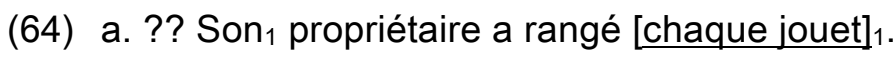

'Its ${ }_{1}$ owner put [each toy $]_{1}$ away.'

b. (?) L'enfant qui l' ${ }_{1}$ a utilisé a rangé [chaque jouet] ${ }_{1}$.

'The child who used it ${ }_{1}$ put [each toy $]_{1}$ away.'

Like (64)b, a version of (63) containing an overt relative comparative clause is acceptable.

(65) Cette semaine, un critique différent de celui qui l'1 a vu la semaine dernière a $\mathrm{vu}$ [chaque film] 1 .

'This week, a critic different from the one that watched it $_{1}$ last week watched [each movie] $]_{1}$ '

Second, the element to be bound is silent and WCO is supposed to hold for explicit pronouns and may not hold for silent elements. Thus, (66) demonstrates that WCO effects do not appear to obtain with silent elements selected by relational nouns.

(66) a. Un voisin procédurier a attaqué en justice chacun de mes amis.

'A litigious neighbor sued each of my friends.'

b. ?? Son 1 voisin procédurier a attaqué en justice [chacun de mes amis] 1. 'His ${ }_{1}$ litigious neighbor sued [each of my friends] $]_{1}$.'

c. Un rival de longue date a trahi chacun de ces gouverneurs.

'A longstanding rival betrayed each of these governors.'

d. ?? Son ${ }_{1}$ rival de longue date a trahi [chacun de ces gouverneurs] ${ }_{1}$.

'His ${ }_{1}$ longstanding rival betrayed [each of these governors] ${ }_{1}$.'

Voisin ('neighbor') in (66)a and rival ('rival') in (66)c contain an implicit argument that can respectively be bound by chacun de mes amis ('each of my friends') and chacun de ces gouverneurs ('each of these governors'). This should yield a WCO effect just as in (66)b and (66)d involving overt bound pronouns; yet the sentences are acceptable under the bound reading, which suggests that WCO effects are at the very least reduced with silent elements.

Thus WCO is to be qualified: the effect depends on the embedding and the overtness of the pronoun. Therefore, it does not constitute an argument against binding of the silent pronoun by the licensor.

In sum, it seems that binding of the silent pronoun by a quantified licensor is possible, but there is no way to decide whether it is obligatory because configurations which would rule out the sentence under the binding hypothesis (the licensor cannot c-command the silent pronoun) are anyway precluded for other reasons, because the pertinent interpretation can obtain without binding, and because Weak Crossover is not relevant in our cases. 
To summarize the section, here are the main cases of standards as CP.

\begin{tabular}{|c|c|}
\hline Case & \\
\hline $\begin{array}{l}\text { Standard as partially } \\
\text { elided comparative clause } \\
\text { ('than [cP remnant]') }\end{array}$ & $\begin{array}{l}\text { (4)' Paul a vu un film différent de [CP } \\
\text { 'Paul watched a different movie than [CP Marie a vu-film]. } \\
\text { wh-movie]. } \\
\text { (5)' J'ai regardé un film différent de [CP Marie } \\
\text { hier]. } \\
\text { 'I watched a dilmed regardé reg-film } \\
\text { movie yesterday].' }\end{array}$ \\
\hline $\begin{array}{l}\text { Standard as fully elided } \\
\text { comparative clause } \\
\text { ('than [CP X]') } \\
\mathrm{X} \text { is underspecified and } \\
\text { can in particular be } \\
\text { interpreted as a pronoun, } \\
\text { a reflexive or a reciprocal. }\end{array}$ & $\begin{array}{l}\text { (12)' Chaque critique a vu un film différent de [CP wh-film X ont vu } \\
\text { wh-film]. } \\
\quad \text { 'Each critic watched a different movie than [CP } \\
\text { watched wh-movie].' } \\
\text { (13)' Paul et Claire ont vu un film différent de [CP wh-film X ont vu } \\
\text { wh-film]. } \\
\text { 'Paul and Claire watched a different movie than [CP } \\
\text { watched wh-movie].' }\end{array}$ \\
\hline
\end{tabular}

Table 2: Standard as CP

\subsubsection{An argument for the presence of CP: island effects}

Recall that at the end of section 2.1, we saw that the pragmatic account proposed by Beck (2000) for cases like (10)' or (32) (case noted 'from X Xeciprocal') correctly predicts that two plural DPs containing différents can be separated by a scope island as in (34) repeated below.

(34) a. Les films que Paul et Claire ont vus sont différents.

'The movies that Frank and Bärbel watched are different.'

b. Paul et Claire ont vu des films qui menaient à des conclusions différentes.

'Paul and Claire watched movies that came to different conclusions.'

Conversely, we will see in this section that cases like (12)' (case noted 'than [CP X]') or (4)' (cases noted 'than [cP remnant]') are sensitive to islands, ${ }^{15}$ which supports the hypothesis that différent is complemented by a silent comparative clause in such cases.

\section{Licensor in island}

First, internal interpretations are unavailable when the licensor (but not différent) is in an island. This follows under the present analysis that supposes the presence of an elided

15 Moltmann (1992) already mentions some island facts in English to argue for the following claim: same/different with a quantified antecedent enters a syntactic relation that is different from the syntactic relation involving anaphors, bound variables and wh-movement, but that is parallel to the syntactic relation between each other and its reciprocal antecedent. 
comparative clause in such cases because the licensor fails to move out of the island: this is a problem when there is a remnant in the comparative clause because the identity condition on ellipsis cannot be satisfied. This is illustrated in (67) (the remnant Paul in (a)-(d) or cette faute-là 'that mistake' in (e) is here extraposed, but the same holds if it is not). ${ }^{16}$ The sentences involve adjunct islands ((67)a, (69)a), coordination islands ((67)b, (69)b), clausal complements of non-bridge verbs ((67)c, (69)c), wh-islands ((67)d, (69)d) and subject islands ((67)e, (69)e).

(67) a. *Une personne différente est en colère parce qu'Anne a vaincu Luc de Paul. 'A different person is angry because Anne beat Luc than Paul.'

Intended interpretation: the person that is angry because Anne beat Luc is different from the person that is angry because Anne beat Paul.

b. * Une personne différente a critiqué Pierre et Luc de Paul.

'A different person criticized Pierre and Luc than Paul.'

Intended interpretation: the person that criticized Pierre and Luc is different from the person that criticized Pierre and Paul.

c. * Une personne différente chuchote qu'Anne a vaincu Luc de Paul.

'A different person whispers that Anne beat Luc than Paul.'

Intended interpretation: the person that whispers that Anne beat Luc is different from the person that whispers that Anne beat Paul.

d. * Une personne différente se demande quand Anne vaincra Luc de Paul.

'A different person wonders when Anne will beat Luc than Paul.'

Intended interpretation: the person that wonders when Anne will beat Luc is different from the person that wonders when Anne will beat Paul.

e. * Que Luc ait fait cette faute-ci déçoit un joueur différent de cette faute-là.

'That Luc made this mistake disappoints a different player than that mistake.'

Intended interpretation: the player that is disappointed because Luc made this mistake is different from the player that is disappointed because Luc made that mistake.

None of the intended interpretations in (67) is available: the only possible interpretation in (a)-(d) - if de Paul was not extraposed - would be that the person in question is different from Paul ( (e) could not be interpreted at all since a player cannot be compared to a mistake).

16 I extrapose it to give more chance to the example. Indeed, extraposed comparative clauses with regular comparatives improve examples where the compared element is not in subject position; this is the case of (x)a repeated below where this equation occurs in object position.

(xi) a. * A smarter student than this equation solved this problem.

b. ? A smarter student solved this problem than this equation.

Intended meaning: a smarter student than the student that solved this equation solved this problem.

Note that this argues in favor of Fox's (2002) analysis of ACD that assumes late insertion of the relative clause. Fox's analysis could be here adopted for the comparative clause of sidi terms and regular comparatives; the present analysis does not hinge on a specific analysis of ACD resolution. 
The unavailability of the internal reciprocal interpretation in all these sentences involving islands is predicted by the proposed analysis because it supposes the presence of an elided comparative clause. Indeed, the same holds with regular comparatives:

(68) *Une personne plus importante est en colère parce qu'Anne a battu Pierre que Marie.

'A more important person is angry because Anne beat Pierre than Marie.'

(68) cannot mean that the person that is angry because Anne beat Pierre is more important than the person that is angry because Anne beat Marie. This is so because Pierre (assumed to be focused under Heim's (1997) analysis) cannot move out of the because clause due to island constraints (adjunct island here) and thus the right antecedent for the ellipsis in the comparative clause cannot be constructed as explained for (40)' in section 2.2.1.

Similarly, internal interpretations are unavailable when the comparative clause is completely silent as exemplified in (69), namely when the licensor appearing in an island is a quantifier.

(69) a. \# Une personne différente est en colère parce qu'Anne a vaincu chaque joueur.

'A different person is angry because Anne beat every player.'

Intended interpretation: for each player that Anne beat, there is a different person who is angry.

b. \# Une personne différente a critiqué Luc et chaque joueur.

'A different person criticized Luc and every player.'

Intended interpretation: Luc is criticized by everybody and each player is criticized by a different person.

c. \# Une personne différente chuchote qu'Anne a vaincu chaque joueur.

'A different person whispers that Anne beat every player.'

Intended interpretation: for each player that was beaten by Anne, there is a different person that whispers that it happened.

d. \# Une personne différente se demande quand Anne vaincra chaque joueur.

'A different person wonders when Anne will beat every player.'

Intended interpretation: for each player, there is a different person that wonders when Anne will beat him.

e. \# Que Luc ait fait chaque faute déçoit un joueur différent.

'That Luc made every mistake disappoints a different player.'

Intended interpretation: for each mistake made by Luc there is a different player that is disappointed.

Internal readings cannot obtain in (69) because chaque joueur 'every player' in (a)-(d) or chaque faute 'every mistake' in (e) would need to move out of the clause for QR 
reasons: the indefinite DP containing différent needs to be outscoped by the quantifier licensor (as explained in section 2.2.2. e.g. for (46) and (47)); but such a movement crosses an island in all these examples. (69) could only mean that the person (in a-d) or the player (in e) is different from a person mentioned in the context (external interpretation).

The previous examples contrast with sentences that contain several clauses but do not involve islands: $(70)$ is better than (69).

(70) \% Une personne différente pense qu'Anne vaincra chaque joueur. 'A different person thinks that Anne will beat every player.'

This sentence is more acceptable than (69) because there is no island precluding QR of the licensor chaque joueur ('every player'), which is necessary to create the right antecedent for the ellipsis.

Note that this sentence is however degraded for some French speakers. This could be explained by the fact that $\mathrm{QR}$ is sometimes assumed to be clause bounded as opposed to wh-movement (cf. a.o. Farkas 1981). Nevertheless, Fox (2000) shows that QR is not clause bounded in the case of ACD. Also, some quantifiers can scope outside their tensed clause ("scope out" phenomenon), as illustrated below where both the widescope and the narrow-scope readings of every are available:

(71) One girl knows what every boy bought for Mary.

In any case, the crucial point here is that (70) is better than (69) and this follows from the proposed analysis.

Différent in island

Conversely, internal interpretations cannot obtain when différent occurs in an island, which also supports the hypothesis that the silent complement of differrent is a clause. Under this analysis, the unavailability of these interpretations comes from the fact that the island constraint is violated both by the wh-movement required in the elided comparative clause and by the movement of the DP containing differrent that is necessary to resolve ACD. The following sentences illustrate these facts.

(72) a. \# Luc est en colère parce qu'Anne a vaincu une personne différente de Paul. 'Luc is angry because Anne beat a different person than Paul.'

Intended interpretation: the person such that Luc is angry because Anne beat her is different from the person such that Paul is angry because Anne beat her.

b. \# Luc a critiqué Pierre et une personne différente de Paul.

'Luc criticized Pierre and a different person than Paul.' 
Intended interpretation: the person such that Luc criticized Pierre and her is different from the person such that Paul criticized Pierre and her.

c. \# Luc chuchote qu'Anne a vaincu une personne différente de Paul.

'Luc whispers that Anne beat a different person than Paul.'

Intended interpretation: the person such that Luc whispers that Anne beat her is different from the person such that Paul whispers that Anne beat her.

d. \# Luc se demande quand Anne vaincra une personne différente de Paul.

'Luc wonders when Anne will beat a different person than Paul.'

Intended interpretation: the person such that Luc wonders when Anne will beat her is different from the person such that Paul wonders when Anne will beat her.

e. \# Que Pierre ait fait une faute différente déçoit Luc de Paul.

'That Pierre made a different mistake disappoints Luc than Paul.'

Intended interpretation: the mistake such that it disappoints Luc that Pierre made it is different from the mistake such that it disappoints Paul that Pierre made it.

(73) a. \# Chaque joueur est en colère parce qu'Anne a vaincu une personne différente.

'Every player is angry because Anne beat a different person.'

Intended interpretation: for each player $\mathrm{x}$, there is a person $\mathrm{y}$ such that $\mathrm{x}$ is angry because Anne beat y.

b. \# Chaque joueur a critiqué Luc et une personne différente.

'Every player criticized Luc and a different person.'

Intended interpretation: for each player $\mathrm{x}$, there is a person $\mathrm{y}$ such that $\mathrm{x}$ criticized Luc and $\mathrm{y}$.

c. \# Chaque joueur chuchote qu'Anne a vaincu une personne différente.

'Every player whispers that Anne beat a different person.'

Intended interpretation: for each player $\mathrm{x}$, there is a person $\mathrm{y}$ such that $\mathrm{x}$ whispers that Anne beat $\mathrm{y}$.

d. \# Chaque joueur se demande quand Anne vaincra une personne différente.

'Every player wonders when Anne will beat a different person.'

Intended interpretation: for each player $\mathrm{x}$, there is a person $\mathrm{y}$ such that $\mathrm{x}$ will be offended if you criticize $y$.

e. \# Que Luc ait fait une faute différente déçoit chaque joueur.

'That Luc made a different mistake disappoints every player.'

Intended interpretation: for each player $\mathrm{x}$, there is a mistake y such that the fact that Luc made y disappoints $\mathrm{y}$.

As in the previous case, the same holds with regular comparatives (as observed e.g. by Kennedy: 2002).

(74) \# Pierre est en colère parce qu'Anne a batu un meilleur joueur que Marie.

'Pierre is angry because Anne beat a better player than Marie.' 
(74) cannot mean that the player that Pierre is angry because Anne beat her/him is better than the player that Marie is angry because Anne beat her/him.

This is due to the fact that this interpretation would require two island violations: one by the movement required for the resolution of ACD (as explained in the previous section, the sidilcomparative term must be moved out of the clause to avoid infinite regression when copying the antecedent in the ellipsis site); the other one by the wh-movement of the degree/sidi term in the elided comparative clause.

However as before, similar sentences (with two clauses) that do not involve islands are crucially acceptable:

(75) Chaque joueur pense qu'Anne vaincra une personne différente. 'Each player thinks that Anne will beat a different player.'

This is so because here, the movement of différent out of the overt clause and the whmovement of différent in the elided comparative clause do not cross an island and are thus possible.

In sum, the island sensitivity shown by internal interpretations supports the proposed analysis based on the presence of an elided comparative clause as complement of différent because these island effects can be accounted for by mechanisms required in the presence of comparative clauses.

\subsubsection{Comparison with comparatives and relational terms}

Comparatives

The present analysis makes différent parallel to a regular comparative in that they are both complemented by comparative clauses. In fact, we have observed that the constructions involving a remnant in the comparative clause are similar:

(4)' Paul a vu un film différent de Marie.

'Paul watched a different movie than Marie.'

(37) Paul a vu un film plus intéressant que Marie.

'Paul watched a more interesting movie than Marie.'

Concerning constructions with fully elided comparative clauses, they are acceptable under the pronominal and reflexive interpretations, but not under the reciprocal interpretation. This is so for both comparatives of inferiority/superiority (cf. (76)) and equatives (cf. (77)). 
(76) a. *Lucie et Claire ont mis une robe plus/moins élégante.

'Lucie and Claire put on a more/less elegant dress.'

b. *Chaque fille a mis une robe plus/moins élégante.

'Each girl put on a more/less elegant dress.'

(77) a. ?Lucie et Claire ont mis une robe aussi élégante.

'Lucie and Claire put on an elegant dress.'

b. ?Chaque fille a mis une robe aussi élégante.

'Each girl put on an as elegant dress.'

Indeed, (76) can only mean that Lucie and Claire or each girl put on a more/less elegant dress than they did themselves at another occasion (reflexive interpretation) or than someone else did (pronominal interpretation): it cannot mean that the dress that each girl put on is more/less elegant than the dress that each other girl put on (this would lead to a contradiction). The corresponding interpretations are more accessible in (77), but the sentences are degraded too.

As in the previous case (cf. section 2.1.2, examples (30) and (31)), I suppose that this is due to the meaning of comparatives: since comparatives are not inherently symmetrical, the underspecified element $X$ present in the elided comparative clause cannot be interpreted as a reciprocal.

This hypothesis is supported by the fact that a pseudo-reciprocal interpretation becomes available with comparatives when the ordering constraint is controlled, e.g. by the presence of chaque ('each'), which can imply succession. ${ }^{17}$

(78) a. Je l'aime un peu plus/moins chaque jour.

'I like her a little more/less every day.'

Intended interpretation: for each day $\mathrm{x}, \mathrm{y}$ such that $\mathrm{y}>\mathrm{x}$ (i.e. $\mathrm{y}$ temporally following $\mathrm{x}$ ), I like her a little more/less on day $y$ than on day $x$.

b. Ce joueur devient meilleur/plus mauvais à chaque match.

'This player gets better/worse at every game.'

Intended interpretation: for each game $\mathrm{x}$, $\mathrm{y}$ such that $\mathrm{y}>\mathrm{x}$ (i.e. $\mathrm{y}$ temporally following $\mathrm{x}$ ), this player gets better/worse at game $y$ than at game $x$.

Relational terms

Relational terms different from different, same or other do not however license elided comparative clauses with a remnant as illustrated in (79) with similaire 'similar' and in (80) with ennemi 'enemy, hostile'.

17 The reason why chaque ('each') can express succession is not my concern here. 
(79) a. ??J'ai mis une robe similaire à hier.

'I put on a similar dress to yesterday.'

Intended interpretation: I put on a dress similar to the dress that I put on yesterday.

b. ??Claire a mis une robe similaire à Lucie.

'Claire put on a similar dress to Lucie.'

Intended interpretation: Claire put on a dress similar to the dress that Lucie put on.

(80) a. *J'ai rencontré un homme ennemi d'hier.

'I met a man hostile to yesterday.'

Intended interpretation: I met a man hostile to the man that I met yesterday.

b. \#Claire a rencontré un homme ennemi de Lucie.

'Claire met a man hostile to Lucie.'

Intended interpretation: Claire met a man hostile to the man that Lucie met.

I therefore hypothesize that there is a selectional difference between différent and relational adjectives like similaire or ennemi: semantically, all combine with two individuals, but syntactically, the former can select a CP (free relative denoting an individual), but the latter cannot; note that this correlates with the fact that the latter do not use a linker typical of comparatives. I suppose that this difference comes from the fact that différent can move and thus resolve ACD as explained in section 2.2.1..

The unavailability of internal readings with fully elided comparative clauses in the cases of similaire or ennemi follows: 18

(81) a. ? Lucie et Claire ont mis une robe similaire.

'Lucie and Claire put on a similar dress.'

Intended interpretation: The dress that Lucie put on is similar to the dress that Claire put on.

b. ? Chaque fille a mis une robe similaire.

'Each girl put on a similar dress.'

Intended interpretation: the dress that each girl put on is similar to the dress that the other girls put on.

(82) a. \# Lucie et Claire ont rencontré un homme ennemi.

'Lucie and Claire met an hostile man.'

Intended interpretation: the man that Lucie met is hostile to the man that Claire met.

\footnotetext{
18 Note that the sentences with similaire (under the intended interpretation) are better than those involving ennemi. This can be related to the fact that the meaning of similaire is close to the meaning of sidi terms (same/different/other): in fact, the same happens with other relational adjectives that denote similar notions like semblable ('similar', 'like'), identique ('identical'), pareil ('the same', 'such'), distinct ('distinct'), dissemblable ('dissimilar')...etc. Thus it seems that other adjectives denoting notions of similarity or difference can be coerced into behaving like sidi terms, i.e. licensing a CP complement. The necessity of coercion yields intermediate judgments.
} 
b. \# Chaque fille a rencontré un homme ennemi.

'Each girl met an hostile man.'

Intended interpretation: the man that each girl met is hostile to the man that the other girls met.

To sum up, I propose that différent can be analyzed in a uniform way without postulating any specific mechanism if we assume that it is a relational adjective that can select a comparative clause: like a relational term, it combines with two individuals and denotes a relation between them; like a comparative, it can select a comparative clause. The difference with the former is that relational terms different from sidi terms cannot combine with comparative clauses; the difference with the latter is that other comparatives deal with degrees, not individuals.

Based on this hypothesis, the variety of constructions comes from the diverse possibilities of constructing the standard: this individual can project as a DP or a CP; such DPs and CPs can be more or less elided and the silent elements can receive various interpretations.

\section{Même and autre}

We will see in this section that this analysis can extend to the other sidi terms même ('same') and autre ('other'). I will show how the few differences between différent and même or autre are due to independent factors.

\subsection{Même ('same')}

\subsubsection{Data}

First, disregarding a difference in determiner that is orthogonal to my main issue here (see appendix B for more about this issue), même exhibits a distribution that is very similar to that of différent.

\begin{tabular}{|l|l|}
\hline \multicolumn{1}{|c|}{ Case } & \multicolumn{1}{c|}{ Example } \\
\hline \multirow{3}{*}{$\begin{array}{l}\text { ('from DP') } \\
\text { (1)" Lucie est la même que Claire. } \\
\text { 'Lucie is the same as Claire.' } \\
\text { (2)" J'ai vu le même film que ce film-là. } \\
\text { 'I watched the same movie as this one.' } \\
\text { (3)" Paul a vu le même film que ce que proposait } \\
\text { Marie. } \\
\text { 'Paul watched the same movie as what Marie } \\
\text { proposed.' }\end{array}$} \\
\hline
\end{tabular}




\begin{tabular}{|c|c|}
\hline $\begin{array}{l}\text { Standard as implicit DP } \\
\text { ('from X') } \\
X \text { is underspecified and can in particular } \\
\text { be interpreted as a pronoun, a reflexive } \\
\text { or a reciprocal. }\end{array}$ & $\begin{array}{l}\text { (6)" Lucie est allée voir Frida hier. Moi, j'ai vu le même } \\
\text { film que X. } \\
\text { 'Lucie watched Frida yesterday. As for me, I } \\
\text { watched the same movie as X.' } \\
\text { (7)" 'WWatching a trailer] C'est le même film que-X que } \\
\text { j'avais vu. } \\
\text { 'It is the same movie as X that I had watched.' } \\
\text { (8)" Ces films sont les mêmes que X. } \\
\text { 'These movies are the same as X.' } \\
\text { (9)" ?J'ai vu les mêmes films que X pendant les } \\
\text { vacances. } \\
\text { 'I watched the same movies as X during the } \\
\text { holidays.' } \\
\text { (10)" Les critiques ont vu les mêmes films que X. } \\
\text { 'The critics watched the same movies-as-X.' } \\
\text { (11)"' Par rapport à la semaine dernière, chaque } \\
\text { enfant est le même que X aujourd'hui. } \\
\text { 'As compared to last week, each child is the same } \\
\text { as X today.' }\end{array}$ \\
\hline $\begin{array}{l}\text { Standard as partially elided comparative } \\
\text { clause } \\
\text { ('than [cP remnant]') }\end{array}$ & $\begin{array}{l}\text { (4)" Paul a vu le même film que [cP } \\
\text { Wh-film]. } \\
\text { 'Paul watched the same movie as [cP wh movie } \\
\text { Marie watched wh-movie].' } \\
\text { (5)" J'ai regardé le même film que [cP } \\
\text { regardé wh-film hier]. } \\
\text { 'I watched the same movie as [cP wh-movie I } \\
\text { watched yesterday].' }\end{array}$ \\
\hline $\begin{array}{l}\text { Standard as fully elided comparative } \\
\text { clause } \\
\text { ('than [cP X]') } \\
\mathrm{X} \text { is underspecified and can in particular } \\
\text { be interpreted as a pronoun, a reflexive } \\
\text { or a reciprocal. }\end{array}$ & $\begin{array}{l}\text { (12)" Chaque critique a vu le même film que [CP wh- } \\
\text { film X ent vu wh-film]. } \\
\text { 'Each critic watched the same movie as [CP } \\
\text { movie X watched wh-movie].' } \\
\text { (13)" Paul et Claire ont vu le même film que [CP } \\
\text { film X ont vu wh-film]. } \\
\text { 'Paul and Claire watched the same movie-as [CP } \\
\text { wh-movie X watched wh-movie].' }\end{array}$ \\
\hline
\end{tabular}

Table 3: main cases with même

Furthermore, the same island facts obtain with même. The internal reading is not available when même is in an island and the licensor is not, as in the cases with différent in (72) and (73). Here, I only illustrate the cases involving an adjunct island:

(83) \# Luc est en colère parce qu'Anne a vaincu la même personne que Paul.

'Luc is angry because Anne beat the same person as Paul.'

Intended interpretation: the person that made Luc angry because Anne beat her is the same as the person that made Paul angry because Anne beat her. 
(84) \# Aucun joueur n'est en colère parce qu'Anne a vaincu la même personne.

'No player is angry because Anne beat the same person.'

Intended interpretation: for each player $\mathrm{x}$, there is a different person $\mathrm{y}$ that made $\mathrm{x}$ angry because Anne beat y.

Note that I here use aucun ('no') as a distributive quantifier for the licensor in (84) because with même, this clearly distinguishes the targeted internal interpretation from the external one: thus in (a), the intended internal interpretation entails that every player is angry because of a different person being beaten by Anne, while under the external interpretation, only one person - the same as a previously mentioned one - would have been defeated (and no player would be angry because of that). It is clear that the sentence cannot express the first situation.

The reverse case - the licensor is an island, unlike même - is however harder to illustrate for the reason I just mentioned. We cannot use aucun as licensor because for independent reasons that I cannot detail here, aucun is not able to take scope over même. ${ }^{19}$ Moreover, another quantifier (e.g. chaque 'every, each' below) makes the internal and the external interpretations hardly distinguishable because only one person is at stake in both cases.

(85) \# La même personne est en colère parce qu'Anne a vaincu chaque joueur.

'The same person is angry because Anne beat every player.'

Internal interpretation: for each player, the person that is angry because Anne beat him is the same as the person that is angry because Anne beat the other players (thus there is only one angry person).

External interpretation: for each player, the person that is angry because Anne beat him is the same as some contextually salient person (thus there is only one angry person).

Nevertheless, the absence of a contextually salient person makes this sentence degraded, which suggests that même resembles différent in this respect too.

\subsubsection{Account for the differences with différent}

The table and examples above demonstrate that même and différent exhibit almost the same behavior. Même only differs from différent in two respects.

Standard as silent DP interpreted as reciprocal

First, there is a contrast between the following two sentences:

19 The following sentence (xii)a cannot have the same meaning as the passive in (xii)b:

(xii) a. Le même joueur n'a remporté aucune partie.

'The same player won no game.'

b. Aucune partie n'a été remportée par le même joueur. 'No game was won by the same player.' 
(9)' J'ai vu des films différents que $X$ pendant les vacances.

'I watched different movies than X during the holidays.'

(9)"' ?J'ai vu les mêmes films que X pendant les vacances.

'I watched the same movies as X during the holidays.'

The reciprocal interpretation of X is salient in (9)' (i.e. I watched movies that are different from each other during the holidays), but it is hardly available in (9)" (i.e. I watched movies that are the same as each other during the holidays).

Here is a possible explanation for this contrast: a complete reciprocal identity (as would be the case under the intended interpretation in (9)" with même) usually amounts to a single object. (86) could thus be pragmatically unfelicitous under the reciprocal interpretation because it can be expressed by a singular as in (87).

(86) ? J'ai mis les mêmes robes la semaine dernière.

'I put on the same dresses last week.'

(87) J'ai mis la même robe la semaine dernière.

'I put on the same dress last week.'

However, we observe that it is possible to use identique ('identical') in these cases.

(88) J'ai mis des robes identiques la semaine dernière.

'I put on identical dresses last week.'

(88) means that last week, I put on several dresses that looked identical. But the plural is here licensed because there are several dresses in question, and they can be said to be identical because they are of the same kind. In other words, (88) is interpretable under a type reading, which involves several objects, not under a token reading involving a single dress. Thus the type/token ambiguity that is orthogonal to the main issue of this paper (see a.o. Alrenga 2007 for more detail) may well play a role in the difference between (9)" and (9)'. My hypothesis is that même preferably gives rise to token readings contrary to identique; that's why (9)" is degraded (the token reading of même favors the use of a singular as in (87)) contrary to (88) (the type reading of identique licenses the plural).

Strikingly, this interpretation with même improves when the type reading is made explicit:

(89) J'ai mis les mêmes genres de robes la semaine dernière.

'I put on the same kinds of dresses last week.'

Moreover, (86) can be licensed under this interpretation if the context is enriched to make the type reading salient as illustrated in (90): 
(90) II y a deux semaines, il a fait si chaud que seules les robes extrêmement légères que j'avais achetées en Afrique étaient mettables. Du coup, cette semaine-là, je n'ai pas fait d'effet de style, j'ai mis les mêmes robes.

'Two weeks ago, it was so hot that only the extremely thin dresses that I had bought in Africa were bearable. So during that week, I didn't look for stylistic change, I put on the same dresses.'

This supports the hypothesis that this difference between même and différent comes from an independent fact: unlike différent or identique, même preferably gives rise to token readings.

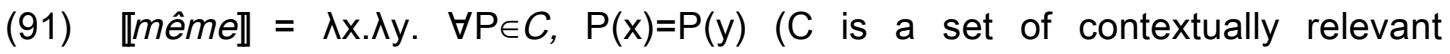
properties, preferably including all possible properties)

Plural as licensor under a reciprocal interpretation

Conversely, même is more permissive than différent in the case where the licensor is a simple plural and the sidi term occurs in a singular DP: it more easily licenses the reciprocal interpretation.

(49) ?Les critiques ont vu un film différent.

'The critics watched a different movie.'

Intended interpretation: each critic watched a different movie than the others.

(92) Les critiques ont vu le même film.

'The critics watched the same movie.'

Intended interpretation: each critic watched the same movie as the others.

Recall that we hypothesized that the internal interpretation is hard to obtain in (49) because the indefinite un film différent ('a different movie') has to be distributively constructed and this is only possible if it is clear in the context that the critics are constituted of different parts (cf. section 2.2.2.).

The difference between (92) and (49) is due to the fact that the reciprocal interpretation in (92) is entailed by the external interpretation (cf. (85) in section 3.1.1.) so that the distributive construal is not necessary: in every situation where the critics watched the same movie as a certain movie (external interpretation), they watched the same movie as each other: only one movie is at play; in (49) however, the internal interpretation involves several movies while the external one involves only one so that the external interpretation does not entail the internal one.

In fact, (92) is degraded if we add the negation and the context does not make the partition of the licensor explicit: 
(93) ?Les critiques n'ont pas vu le même film.

'The critics did not watch the same movie.'

Intended interpretation: each critic watched a different movie than the others.

In (93), the external interpretation does not entail the internal one: for instance, the sentence is true under the first one if all critics watched a certain movie (say, Stalker), which is not the same as a contextual movie (say, Frida); but this is incompatible with the internal reciprocal interpretation requiring that at least two critics watched different movies. Remarkably, the internal interpretation is not easily accessible here just as in (49).

As noticed by an anonymous reviewer, (49) however does not conversely get as natural as (92) in the presence of the negation:

(94) a.? Les critiques n'ont pas vu un film différent.

'The critics did not watch a different movie.'

b. ?Les critiques n'ont pas vu de film différent.

'The critics did not watch any different movie.'

But this case is more complex than (93). First, note that the use of the indefinite article (un film différent 'a different movie') as in (94)a in this case is not natural. This is due to an independent fact in French: the indefinite article under the negation forces the wide scope of the DP (cf. (95)a); for the narrow scope to obtain under the negation, un must be replaced by de as in (94)b and (95)b.

(95) a. Les critiques n'ont pas vu un film.

'The critics did not watch a movie.' i.e. there is a certain movie that the critics did not watch.

b. Les critiques n'ont pas vu de film.

'The critics did not watch any movie.' i.e. the critics watched no movie.

But (94)a is therefore very weak since it is sufficient that there exists a movie (which will necessarily be different from a certain movie) that the critics did not watch. That's probably why this sentence is not very felicitous.

As for (94)b that licenses the narrow scope of the indefinite, it differs from (92) in the sense that the external and the internal interpretations can be distinguished in the case where the negation has wide scope: for instance, (94)b is true under the external interpretation if one critic did not watch a movie different from, say, Frida, i.e. one critic watched Frida, and all the other critics watched different movies; however (94)b is false under the internal interpretation since they watched different movies than each other.

To summarize, I account for the contrast between (49) and (92) in the following way: for the internal reciprocal interpretation to obtain in (49), the licensor 'the critics' needs to be explicitly partitioned as explained in section 2.2.2; this condition is not required in (92) 
because the two interpretations are indistinguishable (in particular, the external interpretation entails the internal one). Therefore, it is not necessary to conclude from this contrast that même and différent intrinsically behave differently as has been argued for English.

In sum, the analysis adopted for différent applies to même. The few differences in data come from independent facts and do not challenge this analysis.

\subsection{Autre ('other')}

\subsubsection{Data}

Autre ('other') mostly behaves like différent and même. The main difference is that the underspecified element cannot be interpreted as a reciprocal. Also, the postnominal and predicative uses of autre are more formal and constrained, but here I will not concentrate on these differences that I take to be orthogonal to my main issue.

\begin{tabular}{|c|c|}
\hline Case & Example \\
\hline $\begin{array}{l}\text { Standard as overt DP } \\
\text { ('from DP') }\end{array}$ & $\begin{array}{l}\text { (1)'”' ? Lucie est autre que Claire. }{ }^{20} \\
\text { 'Lucie is other than Claire.' } \\
\text { (2)"' J'ai vu un autre film que ce film-là. } \\
\text { 'I watched another movie than this one.' } \\
\text { (3)'” Paul a vu un autre film que ce que proposait Marie. } \\
\quad \text { 'Paul watched another movie than what Marie proposed.' }\end{array}$ \\
\hline $\begin{array}{l}\text { Standard as implicit DP } \\
\text { ('from } X \text { ') } \\
X \text { is underspecified and can in } \\
\text { particular be interpreted as a } \\
\text { pronoun or a reflexive (but not } \\
\text { as a reciprocal). }\end{array}$ & 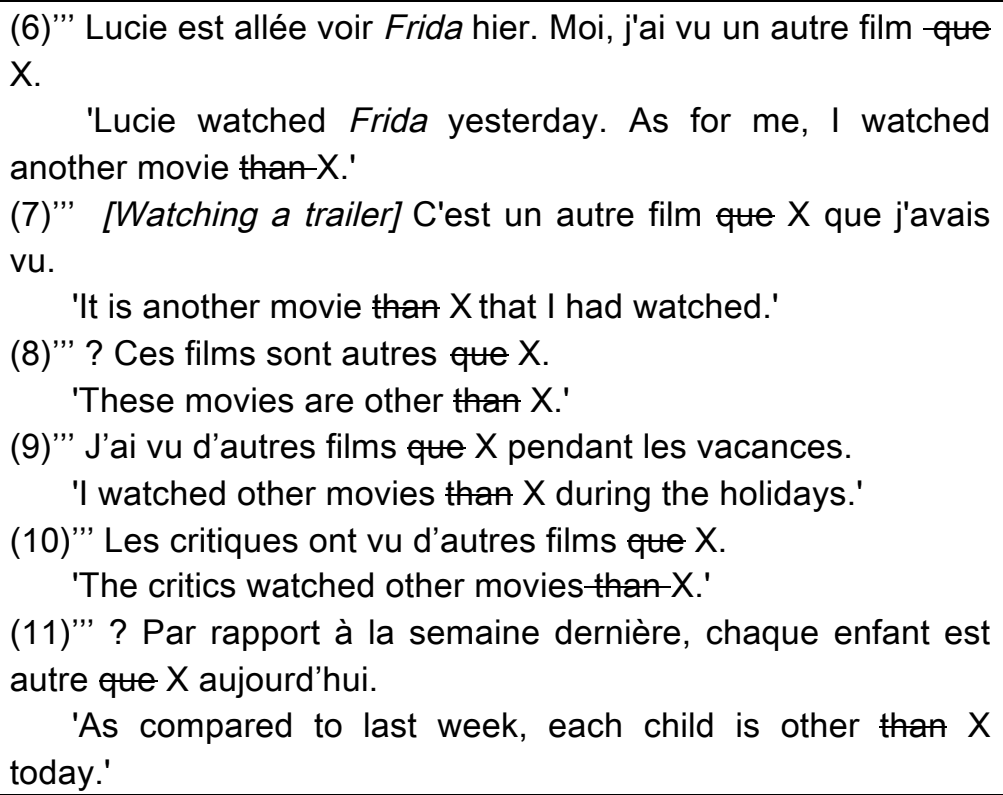 \\
\hline $\begin{array}{l}\text { Standard as partially elided } \\
\text { comparative clause }\end{array}$ & $\begin{array}{l}\text { (4)"' Paul a vu un autre film que [cP wh-film Marie a vu wh-film]. } \\
\text { 'Paul watched another movie than [CP movie Marie }\end{array}$ \\
\hline
\end{tabular}

20 The predicative use of autre is better with a negation or in combination with quelqu'un 'someone':

(xiii) Ma sœur n'est autre que Claire. 'My sister is no other than Claire.' 


\begin{tabular}{|c|c|}
\hline ('than [cP remnant]') & $\begin{array}{l}\text { watched wh-movie].' } \\
\text { (5)'” J'ai regardé un autre film que [CP } \\
\text { film hier]. } \\
\text { 'I watched j'ail regardé wh- } \\
\text { yesterday].' }\end{array}$ \\
\hline $\begin{array}{l}\text { Standard as fully elided } \\
\text { comparative clause } \\
\text { ('than [CP X]') } \\
\mathrm{X} \text { is underspecified and can in } \\
\text { particular be interpreted as a } \\
\text { pronoun or a reflexive (but not } \\
\text { as a reciprocal). }\end{array}$ & $\begin{array}{l}\text { (12)'" Chaque critique a vu un autre film que [cP wh-film X ont } \\
\text { 'Each critic watched another movie than [cP -film]. } \\
\text { watched wh-movie].' } \\
\text { (13)'"' Paul et Claire ont vu un autre film que [cP } \\
\text { 'Pu-film X ont } \\
\text { 'Paul and Claire watched another movie than [cP } \\
\text { movie X watched wh-movie].' }\end{array}$ \\
\hline
\end{tabular}

Table 4: main cases with autre

Moreover, autre is also sensitive to islands. I illustrate this fact using sentences involving adjunct islands and one remnant in the comparative clause.

(96) \# Luc est en colère parce qu'Anne a vaincu une autre personne que Paul.

'LuC is angry because Anne beat the same person as Paul.'

Intended interpretation: the person that made Luc angry because Anne beat her is another person than the person that made Paul angry because Anne beat her.

(97) * Une autre personne est en colère parce qu'Anne a vaincu Luc que Paul. 'Another person is angry because Anne beat Luc than Paul.'

Intended interpretation: the person that is angry because Anne beat Luc is another person than the person that is angry because Anne beat Paul.

\subsubsection{Account for the differences with différent}

These data show that the main difference between différent and autre concerns the reciprocal interpretation of the underspecified element, which is unavailable with autre:

(8)"' \# Ces films sont autres.

'These movies are other.'

Intended interpretation: These movies are different from each other.

(9)"' \# J'ai vu d'autres films pendant les vacances.

'I watched other movies during the holidays.'

Intended interpretation: I watched movies different from each other during the holidays.

(12)"' \# Chaque critique a vu un autre film.

'Each critic watched another movie.'

Intended interpretation: Each critic watched a different movie than the other critics did. 
(13)"' \# Paul et Claire ont vu un autre film.

'Paul and Claire watched another movie.'

Intended interpretation: The movie that Paul watched is another movie than the movie that Claire watched.

In these four sentences, the silent complement can only be interpreted as a pronoun or a reflexive: for instance, (9)"' can mean that I watched movies other than, say, Frida during the holidays (pronominal interpretation) and (12)"' can mean that each critic watched another movie than the movie that (s)he watched the week before (reflexive interpretation).

My hypothesis is that the unavailability of reciprocal interpretations comes from a specific piece of meaning of autre: autre compares two individuals that have to be temporally ordered. ${ }^{21}$ This requirement of temporal succession makes autre an asymmetrical predicate, which precludes the reciprocal interpretation of the underspecified element.

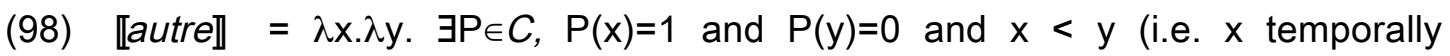
precedes y)

In fact, autre - unlike différent - has a meaning similar to that of ordinals and adjectives such as nouveau 'new' that involve individuals belonging to different time slots:

(99) a. Je voudrais un autre café/un deuxième café/\#un café différent.

'I would like another coffee/a second coffee/\#a different coffee.'

b. D'autres questions ? Vous désirez autre chose ?

'Other questions? Do you want anything else?'

c. J'ai commencé une autre carrière/une nouvelle carrière/\#une carrière différente.

'I've started another career/a new career/\#a different career.'

Also, this hypothesis is corroborated by the fact that when the factor of temporal ordering is controlled by the occurrence of chaque ('each') implying succession, a pseudoreciprocal interpretation gets available with autre, as is the case with comparatives (cf. section 2.2.4.). Autre has a meaning close to nouveau 'new' in this case.

(100)a. Le pessimiste doit s'inventer chaque jour d'autres raisons d'exister. 'Every day, the pessimist must make up other reasons for existing.'

\footnotetext{
${ }^{21}$ The counterpart of autre in the case of identity does not seem to be attested. This is probably because two objects that are identical under a token reading amount to a single object, so an ordering in time is not possible. It is only possible under type readings (two identical objects are then involved), but autre can precisely be used in this case (e.g. (99)a can involve a single kind of coffee, and in fact, identique 'identical' can replace autre in this very example).
} 
b. Chaque nouvelle génération a une autre idée sur la question.

'Each new generation has another idea on the question.'

c. Chaque jour me fait découvrir une autre raison de l'admirer.

'Each day makes me discover another reason for admiring her.'

Similarly, (12)"' improves if we manipulate the context so that each critic is ordered in time, e.g. if each critic works on a different week.

Thus autre is similar to comparatives: its meaning intrinsically has an ordering component, which precludes reciprocal interpretations requiring symmetry. Otherwise, it is similar to différent in being a relational adjective that can combine with comparative clauses.

\section{$4 \quad$ Further issues}

So far, we have seen that the proposed analysis allows us to treat all cases involving différent, même and autre in a uniform way. In this section, we will examine two tricky cases that have contributed to motivating other kinds of analysis: cases involving multiple times and events (section 4.1), and cases involving several sidi terms in the same sentence (section 4.2). We will see that after closer look, these cases do not require a different treatment.

\subsection{Further kinds of licensors}

In the previous sections, we have examined examples involving licensors in the individual domain. But it appears that sidi terms can also take other kinds of licensors: Carlson (1987) and Moltmann (1992) show that same and different are not only licensed by distributive DPs, but also by conjoined PPs, conjoined Ps, conjoined VPs, conjoined Vs, conjoined APs and possibly conjoined Advs, as illustrated by the following examples.

(101)a. Different people discovered America and invented bifocals.

b. John saw and reviewed different films.

c. Max put different plates on the table and in the cupboard.

d. Different people voted for and against the proposal.

e. John painted different houses very red and somewhat blue.

f. (?) John does different tasks eagerly and grudgingly. (from Carlson 1987: 538)

This kind of examples motivated analyses in terms of events (cf. Carlson 1987, Moltmann 1992, Author 2011).

However, note that all examples involved in (101) contain plural DPs with different. Thus they can be analyzed as taking an implicit underspecified DP interpreted as a reciprocal as discussed in section 2.1.2, and the covers determining the relevant interpretation are 
determined pragmatically. For instance in (101)b, the partition of the movies can be made along the dimension of what John did to them \{movies seen by John; movies reviewed by John\}.

Nevertheless, the same kind of examples as (101) can involve singular même:

(102)a. Le même homme composait des opéras et s'endettait régulièrement. 'The same man composed operas and got into debts.'

b. Le même homme composait et jouait des sonates.

'The same man composed and played sonatas.'

c. Le même homme aimait peindre dans son atelier et à l'extérieur.

'The same man liked painting in his studio and outside.'

d. Le même homme a voté pour et contre le projet de loi.

'The same man voted for and against the bill.'

e. Luc a peint le même jouet en rouge et en bleu.

'Luc painted the same toy in red and in blue.'

g. Luc a cuisiné le même plat hier et aujourd'hui.

'Luc cooked the same meal yesterday and today.'

Moreover, même is not only licensed by conjoined elements, but also by other contexts involving plural events (see also Laca and Tasmowski, 2001: ex. 46-48 for similar sentences). They involve several possible aspectual notions (frequentativity, iterativity, habituativity, continuativity, durativity), which can be expressed by several categories (verbs, adverbs, preverbs, nouns, adjectives).

(103) a. Lucie commet souvent la même erreur.

'Lucy often makes the same mistake.'

b. Antoine a lu le même livre plusieurs fois.

'Antoine read the same book several times.'

c. Le film s'arrête à chaque fois sur la même image.

'The movie stops every time on the same picture.'

(104) a. La répétition de la même erreur n'est pas acceptable.

'The repetition of the same mistake is not acceptable.'

b. La deuxième/troisième/quatrième édition du même livre

'The second/third/fourth edition of the same book.'

(105) a. II invite habituellement la même personne chez lui.

'He usually invites the same person at his place.'

b. Il avait coutume d'inviter la même personne chez lui.

'He used to invite the same person at his place.' 
(106) a. Il est difficile de continuer à travailler dans la même entreprise quand on aime le changement.

'It is hard to keep working in the same company when one likes changes.'

b. Le maintien dans le même établissement est de règle pour tout étudiant admis en seconde année ou autorisé à redoubler. [google]

'The maintenance in the same establishment is usual for every student admitted in second year or permitted to repeat the year.'

c. II a un désir constant/continu du même objet.

'He has a constant/continuous desire of the same object.'

(107)a. Annie fait le même repas pour Noël depuis 20 ans.

'Annie has made the same meal for Christmas for 20 years.'

b. Cela fait longtemps que Marc habite au même endroit.

'Marc has been living at the same place for a long time.'

c. Paul a habité au même endroit pendant toute sa jeunesse.

'Paul was living at the same place during his whole youth.'

d. La durée d'habitation dans le même logement est limitée.

'The period of habitation in the same housing is limited.'

e. Une habitation prolongée dans le même logement pourrait poser problème.

'Extended habitation in the same housing could pose problems.'

I hypothesize that this is due to the meaning of identity: two objects that are the same at different times amount to a single object. Therefore, we can simply suppose that the silent complement of même in these cases is interpreted as a reflexive. In fact, indefinites like un $N$ identique ('an identical N') or un seul N ('a single N') can replace the DP with même in all these sentences and yield the same interpretation, which demonstrates that these sentences do not require a specific analysis for même.

(102)' a. Un seul homme composait des opéras et s'endettait régulièrement. 'A single man composed operas and got into debts.'

g. Luc a cuisiné un plat identique hier et aujourd'hui.

'Luc cooked an identical meal yesterday and today.'

Strikingly, similar examples with singular différent are hardly acceptable.

(102)a" ?? Un homme différent composait des opéras et s'endettait régulièrement. 'A different man composed operas and got into debts.'

This is because the reflexive interpretation of the silent complement is contradictory in this case under a token reading, since two objects need to be involved.

However, we saw that the silent complement of différent can be interpreted as a reflexive in certain conditions (cf. (11)'), i.e. if we deal with a single individual that changes over time. In fact, (102)" becomes acceptable under this interpretation, i.e. if we 
understand that only one man is involved (i.e. Mozart) but he is in different states of mind when he composes operas and gets into debts.

The only available example that involves two different objects with singular différent is the equivalent of (103)c:

(103)c' Le film s'arrête à chaque fois/toujours sur une image différente. 'The movie stops every time/always on a different picture.'

This example involves a universal quantifier of time. Thus the proposed analysis can be extended to this case if we assume that the silent elements do not necessarily refer to individuals, but can also be variables in other domains such as times; note that such variables have independently been argued for (cf. Partee: 1989). This can be represented and paraphrased as below.

(108) a. Le film s'arrête toujours sur une image différente de [cP wh-image il s'arrête wh-image $X_{\text {reciprocal }}$.

'The movie always stops on a different picture than [cP wh-picture it stopped wh-picture $X_{\text {reciprocall.' }}$

b. Le film s'arrête toujours sur une image différente de celle sur laquelle il s'arrête les autres fois.

'The movie always stops on a different picture than the one on which it stopped at other times.'

Thus the type of examples that motivated analyses in terms of events can be accounted for by the proposed analysis: just as in examples analyzed previously, sidi terms involve a silent underspecified complement in these cases, which can belong to the domain of times. ${ }^{22}$

\subsection{Double sidi term in the same sentence}

Further tricky examples are as follows.

22 As noted by a reviewer, différent can be used to compare clausal elements as in (xiv):

(xiv) Voyager seul est différent de voyager en groupe.

'To travel alone is different than to travel with a group.'

It seems that these clausal elements are treated like (abstract) individuals in those cases: 'to travel' is equivalent to 'the fact of travelling', 'a travel'. The fact that equivalent sentences with même have to involve the noun chose 'thing' as shown in (xv) support this hypothesis. The construction in (xvi) with différent also contains chose.

(xv) Voyager seul n'est pas la même chose que (de) voyager en groupe.

'To travel alone is not the same thing as to travel with a group.'

(xvi) Voyager seul et voyager en groupe sont deux choses différentes.

'To travel alone and to travel with a group are two different things.'

A detailed examination of such examples is nevertheless beyond the scope of this paper. 
(109)a. Les mêmes enfants ont fait les mêmes erreurs.

'The same children made the same mistakes.'

b. Différents linguistes sont allés à différentes conférences.

'Different linguists went to different conferences.'

They have posed problems to most previous analyses because they seem to require mutual binding of variables. In particular, scope-based analyses propose that the sidi term is a quantifier moving to the right position with respect to the licensor to get interpreted (cf. a.o. Barker 2007): this predicts infinite recursion in these sentences, since the licensor and the target need to be conversely the target and the licensor at the same time (at LF).

According to Keenan (1992: 202), a sentence such as (109)b would mean (on its weakest reading) that there are at least two linguists and for all distinct linguists $x, y$, the conferences that $x$ went to are not exactly the same as the conferences $y$ went to: according to him, the iterated use of different guarantees (minimally) a one-to-one match between linguists and sets of conferences (as well as the existence of at least two linguists). Thus different linguists and different conferences are not interpreted independently according to him.

However, this kind of sentence can get weaker and vaguer interpretations than what Keenan claims: an exact one-to-one match between linguists and sets of conference is not necessary. Thus (109)b could be utterable and deemed true in situations where many linguists went to many conferences and two of them went to exactly the same set of conferences. Moreover, note that (109) involves plural DPs. Therefore, it seems reasonable to suppose that (109) involves silent underspecified complements as in e.g. (10)', which can be interpreted based on pragmatically determined covers. (109)b is roughly paraphrasable as "linguists different from each other went to conferences different from each other" exhibiting many more interpretations, more or less pragmatically plausible; the only requirement is that linguists differ from each other along some dimension and conferences too (see Author 2012 for more detail).

In sum, given that the examples that seem to be problematic for most analyses involve sidi terms occurring in plural DPs, the present analysis can apply to them since the various interpretations of such cases can depend on pragmatics.

\section{Comparison with other analyses and other languages}

In this last section, I will briefly compare the present analysis to previous ones and see how it could extend to other languages than French.

\subsection{Comparison with previous analyses}

\subsubsection{The goals of the present analysis}


What the present paper has strived to achieve (for French) is to derive all constructions involving different, same and other in a uniform way, i.e. without postulating different lexical entries. This is done by relating sidi terms to relational terms and comparatives so that no specific mechanism needs to be postulated: in a nutshell, sidi terms are comparatives of individuals. Theoretically, this approach is motivated by ideals of economy, and empirically, by the observation that most languages (all languages surveyed in the appendix) present the same term for same through all constructions.

Nevertheless, note that we have distinguished between two subcases depending on whether the individual corresponding to the standard is projected as a DP or a CP (comparative clause interpreted as a free relative) just as has been argued for comparatives by linguists assuming the existence of phrasal vs. clausal comparatives (cf. a.o. Hankamer 1973, Napoli 1983). Moreover, we have assumed that some apparent DPs correspond to reduced comparative clauses (cf. section 2.2.1.) just as some other linguists suppose that apparent phrasal comparatives involve reduced comparative clauses (cf. a.o. Heim 1985, Hackl 2000, Lechner 2001, Pancheva 2006).

(4)' Paul a vu un film différent de Marie.

'Paul watched a different movie than Marie.'

(5)' J'ai regardé un film différent d'hier.

'I watched a different movie than yesterday.'

We have done so in cases where the DP in question (e.g. Marie in (4)', yesterday in (5)') cannot directly correspond to the standard due to its meaning. Moreover, island facts argue for the presence of an elided clause.

But what about cases like (2)' where the DP directly corresponds to the standard?

(2)' J'ai vu un film différent de ce film-là.

'I watched a movie different from this one.'

In (2)', ce film-là ('this movie') directly denotes the standard since différent here compares two movies.

As we have mentioned, similar cases are possible with regular comparatives:

(18) J'ai vu un film plus intéressant que ce film-là.

'I watched a movie more interesting than this one.'

We could make the analysis even more unified by supposing that these cases also involve reduced comparative clauses with the verb être 'be'.

(2)' J'ai vu un film différent de ce qu'est ce film-là.

'I watched a movie different than what this one is.' 
(18) J'ai vu un film plus intéressant que ne l'est ce film-là.

'I watched a movie more interesting than this one is.'

This would make sidi terms closer to comparatives than to relational adjectives; and indeed, relational adjectives do not have the same behavior as sidi terms because they cannot combine with comparative clauses (as explained in section 2.2.4) while the difference with comparatives comes from the asymmetrical meaning of comparatives (required for the reciprocal interpretation), which is also observed with autre.

This hypothesis is therefore attractive, in particular for même and autre that require the same linker as comparatives, namely que. However, the nature of the linker and the possibility of selecting comparative clauses do not completely correlate. In particular, différent usually requires the linker de (que is colloquial), i.e. the same linker as many relational terms (e.g. ennemi 'enemy') that do not license comparative clauses; conversely, pareil 'similar' requires the linker que, i.e. the same linker as comparatives, but does not license comparative clauses. Also, the split between DP and CP cases will allow us to account for other possibilities of lexicalization in other languages in section 5.2 , which would be harder to do under a fully unified analysis. For these reasons, I here choose to distinguish between the DP and the CP cases, but it would be worth further investigating whether sidi terms could be analyzed as always taking CP complements.

\subsubsection{Previous analyses}

To the best of my knowledge, the present analysis differs from previous ones in aiming at relating all constructions involving different, same and other, and in proposing no specific mechanism for these terms but in relating them to comparatives and relational terms. Below are some illustrations of this difference, but obviously, I cannot be exhaustive nor detailed about previous analyses.

Barker (2007)'s proposal is radically different: he concentrates on the internal reading of same (cases such as (12)' or (13)'), which he analyzes as a quantificational adjective taking parasitic scope over some other scope-taking element, and this analysis is implemented within an innovative continuation-based Type-Logical Grammar. Thus under this analysis, the internal reading is not related to other constructions involving same, but receives a specific analysis unrelated to other elements of the language like comparatives or relational terms.

Dowty (1985), Carlson (1987) and Moltmann (1992) group some of the constructions together, but none of these analyses relates constructions involving linkers with those without linkers. Dowty (1985) analyzes the discourse anaphoric interpretation and the internal reading such as (12)' as cases of anaphora by giving an important role to pragmatics. Carlson (1987) and Moltmann (1992) treat (12)' or (13)' in a similar way by taking different to distribute over plural events; thus the internal reading is not related to constructions with linkers under these proposals, and same and different are specific and unrelated to comparatives and relational terms.

Brasoveanu (2011) proposes a unified account of sentence-external and sentence- 
internal readings of singular different in a stack-based dynamic system couched in type logic. But he distinguishes between singular different, plural different and same and only focuses on constructions without linkers; thus he does not relate different to comparatives and relational terms.

Heim (1985) however suggests to relate different with comparatives, but she does not discuss internal readings like (12)' or reciprocal interpretations.

Beck (2000) is closer in spirit to the present analysis since she groups several cases together. In particular, she explicitly relates different to relational terms and comparatives. But based on German, she proposes two lexical entries for different: one corresponding to a relational term (German verschieden, which denotes a relation between two individuals) and one corresponding to a comparison operator (German anders, which expresses a relation between a pair of individuals and a relation between two individuals). Note that this leads to a homonymy hypothesis for same too, which is not supported by the German data (this issue is not evoked by Beck): the distinction between German selb and gleich reflects the independent type/token distinction very much like same vs. identical, and thus does not align with the difference between anders and verschieden; selb and gleich do not appear in different constructions and thus do not support the hypothesis of a split between two sets of cases. Instead of supposing two different entries like Beck (2000), I here propose that different always selects two individuals, but the standard can either be a DP or a CP. Thus in the anders case, I assume the presence of an elided comparative clause (interpreted as a free relative, thus denoting an individual) while Becks builds it into the lexical entry of anders. The present analysis has the advantage of directly accounting for the island facts: Beck (2000) does account for why verschieden is not subject to islands as mentioned in section 2.1.2, but it is less clear how all island facts derive from her analysis of anders. Furthermore, I suppose underspecification of (part of) the complement of sidi terms, which correctly predicts interpretations that are not mentioned by Beck (2000) such as reflexive ones. In short, the present analysis is similar to Beck's concerning the cases with DP complements; but the cases that I analyze as taking elided comparative clauses correspond to a different lexical entry in her analysis.

In sum, the previous analyses of same or different - to my knowledge - propose several lexical entries for these terms and rarely relate them to other elements like relational terms or comparatives, but postulate specific mechanisms to account for them. In this paper, I however strived to propose a uniform, non-specific analysis of sidi terms.

\subsection{Comparison with other languages}

Beyond theoretical economy, the main motivation for my enterprise is empirical: sidi terms - in particular same - usually exhibit the same item through all constructions as illustrated in appendix $A$ in a range of various languages, and the presence of homonymy in so many languages seems dubious. Nevertheless, it remains the case that different can be lexicalized in different ways as shown e.g. in Beck (2000) for German. 
How do we explain the possibility of various lexicalizations if we assume a unified account for all cases?

The possibility of several lexical entries for sidi terms can come from two sources. First, as we have seen for French différent vs. autre, two sidi terms can differ on dimensions that are independent from the variety of cases explained here even if they can interact: autre includes an additional meaning component, i.e. requires ordering in time; the difference between selb and gleich corresponds to the difference between token and type readings. More generally, sidi terms can be lexicalized differently depending on how difference and identity are conceptualized, but this issue is orthogonal to ours, i.e. the existence of various constructions involving sidi terms. The second source is however related to our issue and is represented e.g. by the distinction between German verschieden and anders. We have distinguished between cases where the standard selected by the sidi term is projected as a DP and cases where it is a comparative clause; these two selectional subcases can correlate with two different lexicalizations as I assume is the case in German. Based on the data in the appendix, this seems to only occur with different, not with same. But this apparent difference vanishes if we incorporate other relational terms expressing identity like identical: identical seems to be the counterpart of verschieden in that it only selects DPs, not comparative clauses. Thus the possibility of selecting comparative clauses or not can determine different lexicalizations. This is usually reflected by the nature of the linker, similar or not to that of comparatives, but not always (cf French différent selecting de like relational terms or que like comparatives). As already mentioned, this occasional mismatch between linkers and selectional restriction is a mystery that would require further investigation.

\section{Conclusion}

In this paper, I strived to account for all uses of sidi terms in a unified way without resorting to specific mechanisms. The main argument for endorsing this approach is the strong crosslinguistic evidence with respect to the identity term equivalent to same: in all the languages that I have surveyed (see appendix A), only one term is devoted to all constructions; this strongly suggests that all the readings should be derived from a unique lexical entry.

This analysis relates sidi terms to both relational terms and comparatives and it is based on the possible presence of underspecified silent elements that can be pragmatically interpreted in different ways. Here is a summary of all readings with sidi terms:

\begin{tabular}{|c|c|l|}
\hline Case & \multicolumn{1}{|c|}{ Explanation } & \multicolumn{1}{c|}{ Examples involving différent } \\
\hline & & (1)' Lucie est différente de Claire. \\
'Lucie is different from Claire.' \\
$\begin{array}{c}\text { Standard as } \\
\text { overt DP }\end{array}$ & $\begin{array}{c}\text { The complement of the sidi } \\
\text { term is an explicit DP } \\
\text { ('from DP') }\end{array}$ & $\begin{array}{l}\text { (2) J'ai vu un film différent de ce film-là. } \\
\text { 'I watched a movie different from this one.' }\end{array}$ \\
& $\begin{array}{l}\text { (3) Paul a vu un film différent de ce que proposait } \\
\text { Marie. }\end{array}$ \\
\hline
\end{tabular}




\begin{tabular}{|c|c|c|}
\hline & & $\begin{array}{l}\text { 'Paul watched a different movie than what Marie } \\
\text { proposed.' }\end{array}$ \\
\hline $\begin{array}{l}\text { Standard as } \\
\text { implicit DP } \\
\text { ('from X') }\end{array}$ & $\begin{array}{l}\text { The complement of the sidi } \\
\text { term is a silent DP that is } \\
\text { underspecified. It can be } \\
\text { pragmatically interpreted as } \\
\text { an anaphoric or deictic } \\
\text { pronoun, a reflexive, a } \\
\text { reciprocal or more vaguely. }\end{array}$ & $\begin{array}{l}\text { (6)' Lucie est allée voir Frida hier. Moi, j'ai vu un film } \\
\text { différent-de-X. } \\
\text { 'Lucie went and watched Frida yesterday. As for } \\
\text { me, I watched a different movie from X.' } \\
\text { (7)' [Watching a trailer] C'est un film différent de-X que } \\
\text { j'avais vu. } \\
\text { 'It is a different from X movie that I had watched.' } \\
\text { (8)' Ces films sont différents de X. } \\
\text { 'These movies are different from X.' } \\
\text { (9)' J'ai vu des films différents de X pendant les } \\
\text { vacances. } \\
\text { 'I watched different movies frem X during the } \\
\text { holidays.' } \\
\text { (10)' Les critiques ont vu des films différents de X. } \\
\text { 'The critics watched different movies.' } \\
\text { (11)' Par rapport à la semaine dernière, chaque enfant } \\
\text { est différent de X aujourd'hui. } \\
\text { 'As compared to last week, each child is different } \\
\text { from X today.' }\end{array}$ \\
\hline $\begin{array}{l}\text { Standard as } \\
\text { partially elided } \\
\text { comparative } \\
\text { clause } \\
\text { ('than [cP } \\
\text { remnant]') }\end{array}$ & $\begin{array}{l}\text { The complement of the sidi } \\
\text { term is a partially elided } \\
\text { comparative clause. }\end{array}$ & $\begin{array}{l}\text { (4)' Paul a vu un film différent de [CP } \\
\text { 'Ph-film]. } \\
\text { 'Paul watched a different movie than [CP a vu movie } \\
\text { Marie watched wh-movie]. } \\
\text { (5)' J'ai regardé un film différent de [CP } \\
\text { regardé wh-film hier]. } \\
\text { 'I watched a different movie than [CP wh-movie I } \\
\text { watched yesterday].' }\end{array}$ \\
\hline $\begin{array}{l}\text { Standard as } \\
\text { fully elided } \\
\text { comparative } \\
\text { clause } \\
\text { ('than [cP X]') }\end{array}$ & $\begin{array}{l}\text { The complement of the sidi } \\
\text { term is a comparative clause } \\
\text { that is fully elided and } \\
\text { contains a silent } \\
\text { underspecified pronoun, } \\
\text { which can in particular be } \\
\text { interpreted as a pronoun, a } \\
\text { reflexive or a reciprocal }\end{array}$ & $\begin{array}{l}\text { (12)' Chaque critique a vu un film différent de [CP wh- } \\
\text { film X ent vu wh-film]. } \\
\text { 'Each critic watched a different movie-than [CP } \\
\text { wh-movie X watched wh-movie].' } \\
\text { (13)' Paul et Claire ont vu un film différent-de [CP } \\
\text { film X ont vu wh-film]. } \\
\text { 'Paul and Claire watched a different movie-than } \\
\text { [cP wh-movie X watched wh-movie].' }\end{array}$ \\
\hline
\end{tabular}

Table 5: Summary of all cases

Thus this analysis rests on the combination of different independently required mechanisms, so that the use of the same term in all uses (cf. equivalent of same in all languages surveyed) is expected. However, it also makes possible specific lexicalizations since several parameters are involved (selection of DP/CP, meaning specificities...). The study of more crosslinguistic data would be useful to further elaborate an analysis that does not force multiplication of lexical entries when it is not empirically motivated, but makes it possible when it is observed. In particular, it would 
allow us to better understand what impact the nature of linkers has on the variety of constructions involving sidi terms.

\section{Acknowledgements}

Many thanks to Philippe Schlenker, Benjamin Spector and Dominique Sportiche for helpful comments and discussion. I am also very grateful to all the people who generously answered my crosslinguistic survey, in particular Sameer ud Dowla Khan, Lilit Kocharyan, Grace Kuo, José María Lahoz Bengoechea, Walter Lee, Felipe Lopez, Asuka Matsumoto, Antonio Mele, Pam Munro, WeiSong Ong, Öner Özçelik, Denis Paperno, Fernanda Pratas, Ankelien Shippers, Catherine Willmond and Phran Zutha.

\section{References}

Alrenga, Peter, 2007: Dimensions in the semantics of comparatives. Doctoral dissertation, University of California, Santa Cruz.

Barker, Chris, 2007: "Parasitic Scope". Linguistic and Philosophy 30. 407-444.

Beck, Sigrid, 2000: "The Semantics of different. Comparison Operator and Relational Adjective". Linguistics and Philosophy 23, 101-139.

Brasoveanu, Adrian, 2011: "Sentence-internal different as Quantifier-internal Anaphora". Linguistics and Philosophy 34: 93-168.

Caponigro, Ivano, 2004: "The semantic contribution of wh-words and type shifts:

Evidence from free relatives crosslinguistically". Proceedings of Semantics and Linguistic Theory (SALT) XIV, R. Young (ed.), 38-55. Ithaca, NY: CLC Publications, Cornell University.

Carlson, Greg, 1987: Same and Different: some Consequences for Syntax and Semantics. Linguistics and Philosophy 10.

Chomsky, Noam, 1977: "On Wh-Movement". P. Culicover, T. Wasow and A. Akmajian (eds.) Formal Syntax. New York: Academic Press.

Cinque, Guglielmo, 2010: The Syntax of adjectives: a Comparative Study. Linguistic Inquiry Monographs 57. MIT Press: Cambridge, MA.

Dotlačil, Jakub, 2010: Anaphora and Distributivity. A study of same, different, reciprocals and others, Doctoral Dissertation, Utrecht Institute for Linguistics OTS, LOT Series.

Dowty, David, 1985: "A Unified Indexical Analysis of Same and Different, A Response to Stump and Carlson", Paper presented at the University of Texas Workshop on Syntax and Semantics, Austin, Texas, March 22-24, 1985.

Farkas, Donka, 1981: "Quantifier scope and syntactic islands". CLS 17, 59-66.

Fox, Danny, 2000: Economy and Semantic Interpretation. MIT Press.

Fox, Danny, 2002: "Antecedent Contained Deletion and the Copy Theory of Movement". Linguistic Inquiry 33.1, 63-96.

Hackl, Martin, 2000: Comparative Quantifiers. PhD thesis. MIT.

Hankamer, Jorge, 1973: "Why there are two than's in English". Chicago Linguistics Society, 179-91. 
Heim, Irene, 1985: "Notes on Comparatives and Related Matters". Ms, University of Texas, Austin.

Heim, Irene, 1997: "Predicates or Formulas? Evidence from Ellipsis". In A. Lawson (ed.) Proceedings of SALT 7, CLC, Cornell Univ., Ithaca, 197-221.

Heim, Irene, 2000: "Degree Operators and Scope". SALT X, Cornell University, 40-64.

Keenan, Edward, 1992: "Beyond the Frege Boundary". Linguistics and Philosophy 15 (2). $199-221$.

Kennedy, Christopher, 1997: "Antecedent Contained Deletion and the Syntax of Quantification". Linguistic Inquiry 28-4.

Kennedy, Christopher, 1999: Projecting the Adjective: The Syntax and Semantics of Gradability and Comparison. Garland Press, New York.

Kennedy, Christopher, 2002: "Comparative Deletion and Optimality in Syntax". Natural Language and Linguistic Theory 20.3, 553-621.

Laca, Brenda and Liliane Tasmowski, 2001: "Distributivité et interprétations dépendantes des expressions d'identité". In G. Kleiber, B. Laca and L. Tasmowski (eds.), Typologie des groupes nominaux. Rennes: Presses Universitaires de Rennes, 143-166.

Lechner, Winfried, 2001: "Reduced and phrasal comparatives". Natural Language and Linguistic Theory 19, 683-735.

Loebner, Sebastian, 1987: "The Conceptual Nature of Natural Language Quantification". I. Ruzsa and A. Szabolcsi (eds.), Proceedings of the '87 Debrecen Symposium on Logic and Language, Akademiai Kaido, Budapest.

Magri, Giorgio, 2014: "An Account for the Homogeneity Effects triggered by Plural Definites and Conjunction based on Double Strengthening. Semantics, Pragmatics and the Case od Scalar Implicatures; Salvatore Pistoia Reda (ed.); Palgrave.

Matushansky, Ora and Eddy Ruys, 2007: "Same in Russian". Paper presented at FSiM 3, April 28, 2007, Moscow.

Moltmann, Friederike, 1992: "Reciprocals and same/different: towards a Semantic Analysis". Linguistics and Philosophy 15. 411-462.

Napoli, Donna-Jo, 1983: "Comparative Ellipsis: A Phrase Structure Account". Linguistic Inquiry 14, 4, 675-694.

Pancheva, Roumyana, 2006: "Phrasal and Clausal Comparatives in Slavic". FASL 14, 236-257.

Partee, Barbara, 1989: "Binding Implicit Variables in Quantified Contexts". CLS 25.

Rett, Jessica, 2010: "Equatives, measure phrases and NPIs". Amsterdam Colloquium Proceedings.

Schwarzschild, Roger, 1993: "Plurals, Presuppositions and the Sources of Distributivity". Natural Language Semantics 2, 201-248.

Schwarzschild, Roger, 1996: Pluralities, Kluwer, Dordrecht.

Solomon, Mike, 2009: "Partitives and the Semantics of same". Sinn und Bedeutung 14 handout. 
Sportiche, Dominique, 2005: "Division of Labor between Merge and Move: Strict Locality of Selection and Apparent Reconstruction Paradoxes". Proceedings of the Workshop Divisions of Linguistic Labor, The La Bretesche Workshop.

Szabolcsi, Anna, 1997: 'Strategies for Scope Taking'. Szabolcsi (ed) Ways of Scope Taking, Kluwer, 109-154.

Tovena, Lucia and Marleen Van Peteghem, 2006: "La place de différent dans le syntagme nominal et les déterminants". In Indéfinis et Prédications, Francis Corblin, Sylvie Ferrando et Lucien Kupferman (eds.). Presses Universitaires de Paris-Sorbonne. 449-460.

Van Peteghem, Marleen, 1997: "Sur un indéfini marginal: même exprimant l'identité". Langue française 116, 61-80.

\section{Appendix}

\section{A. Crosslinguistic data about same and different}

The following charts present data about sidi terms in different language families:

- 9 Indoeuropean languages: 3 Germanic languages (English, German and Dutch); 4 Romance languages (French, Italian, Spanish and Portuguese), 1 Slavic language (Russian), 1 Armenian language, 1 Indo-Iranian language (Bengali)

- 1 Semitic language (Hebrew)

- 2 Altaic languages (Turkish, Japanese; but this family is controversial, this may correspond to two different families)

- 1 Tai language (Thai)

- 1 Sino-Tibetan language (Taiwanese)

- 1 Austronesian language (Malay)

- 1 Bantu language (Swahili)

- 1 Muskogean language (Chickasaw)

- 1 Oto-Maguean language (Zapotec)

This sample is not balanced across families, and has been constituted informally. Nevertheless, it suggests that the main tendency is as follows: languages present one term for same across the main cases studied in the article, but possibly different ones for different. It would be interesting to test this claim with a more controlled and representative survey. 


\section{A.1. Crosslinguistic data about same ${ }^{23}$}

Most languages present only one word for same in the different cases that have been examined in the article (only some of them are represented below for space reasons).

Moreover, when languages present several words for same, these different words are not distributed over the mentioned constructions (e.g. one for the external reading, the other one for the internal reading), but they differ on other dimensions (cf. type/token reading in German gleich vs. selb) that are not relevant in this paper.

Other languages (e.g. Russian, Swahili) do not appear to express identity in the same way (there does not seem to be any corresponding adjective meaning same); these cases would need further investigation (see Matushansky and Ruys: 2007 for more about same in Russian).

\begin{tabular}{|c|c|c|c|c|}
\hline & $\begin{array}{c}\text { Plural sentence- } \\
\text { internal case }\end{array}$ & $\begin{array}{c}\text { Quantified } \\
\text { sentence- } \\
\text { internal case }\end{array}$ & $\begin{array}{c}\text { Sentence- } \\
\text { external case }\end{array}$ & $\begin{array}{c}\text { Case with overt } \\
\text { linker }\end{array}$ \\
\hline \multirow{2}{*}{ English } & the same & the same & the same & the same as \\
\hline & $\begin{array}{l}\text { Anne and Mike read } \\
\text { the same book. }\end{array}$ & $\begin{array}{l}\text { Every child read the } \\
\text { same book. }\end{array}$ & $\begin{array}{l}\text { Paul decided to read } \\
\text { the Odyssey. I chose } \\
\text { the same book. }\end{array}$ & $\begin{array}{l}\text { I read the same book } \\
\text { as Paul. }\end{array}$ \\
\hline \multirow[t]{2}{*}{ French } & le même & le même & le même & le même que \\
\hline & $\begin{array}{l}\text { Anne et Michel ont lu } \\
\text { le même livre. }\end{array}$ & $\begin{array}{l}\text { Chaque enfant a lu le } \\
\text { même livre. }\end{array}$ & $\begin{array}{l}\text { Paul a décidé de lire } \\
\text { l'Odyssée. J'ai choisi } \\
\text { le même livre. }\end{array}$ & $\begin{array}{l}\text { J'ai lu le même livre } \\
\text { que Paul. }\end{array}$ \\
\hline \multirow[t]{2}{*}{ Italian } & lo stesso & lo stesso & lo stesso & lo stesso di \\
\hline & $\begin{array}{l}\text { Anne e Michel hanno } \\
\text { letto lo stesso libro. }\end{array}$ & $\begin{array}{l}\text { Ogni bambino ha letto } \\
\text { lo stesso libro. }\end{array}$ & $\begin{array}{l}\text { Paul ha deciso di } \\
\text { leggere l'Odissea. lo } \\
\text { ho scelto lo stesso } \\
\text { libro. }\end{array}$ & $\begin{array}{l}\text { lo ho letto lo stesso } \\
\text { libro di Paul. }\end{array}$ \\
\hline \multirow[t]{2}{*}{ Spanish } & el mismo & el mismo & el mismo & el mismo que \\
\hline & $\begin{array}{l}\text { Ana y Miguel leyeron } \\
\text { el mismo libro. }\end{array}$ & $\begin{array}{l}\text { Todos los niños } \\
\text { leyeron el mismo } \\
\text { libro. }\end{array}$ & $\begin{array}{l}\text { Pablo decidió leer la } \\
\text { Odisea. Yo elegí el } \\
\text { mismo libro. }\end{array}$ & $\begin{array}{l}\text { Yo leí el mismo libro } \\
\text { que Pablo. }\end{array}$ \\
\hline \multirow[t]{2}{*}{ Portuguese } & o mesmo & o mesmo & o mesmo & o mesmo que \\
\hline & $\begin{array}{l}\text { A Anne e o Mike } \\
\text { leram o mesmo livro. }\end{array}$ & $\begin{array}{l}\text { Todas as crianças } \\
\text { leram o mesmo livro. }\end{array}$ & $\begin{array}{l}\text { O Paul decidiu ler a } \\
\text { Odisseia. Eu escolhi o } \\
\text { mesmo livro. }\end{array}$ & $\begin{array}{l}\text { Eu li o mesmo livro } \\
\text { que o Paul. }\end{array}$ \\
\hline \multirow[t]{2}{*}{ Dutch } & $\begin{array}{l}\text { hetzelfde } \\
\text { the.same }\end{array}$ & $\begin{array}{l}\text { hetzelfde } \\
\text { the.same }\end{array}$ & $\begin{array}{c}\text { hetzelfde/datzelfde } \\
\text { the.same/that }\end{array}$ & $\begin{array}{l}\text { hetzelfde als } \\
\text { the.same as }\end{array}$ \\
\hline & $\begin{array}{l}\text { Anne en Mike lezen } \\
\text { hetzelfde boek. }\end{array}$ & $\begin{array}{l}\text { leder kind leest } \\
\text { hetzelfde boek. }\end{array}$ & $\begin{array}{l}\text { Paul besloot de } \\
\text { Odysseus te lezen. Ik } \\
\text { koos } \\
\text { hetzelfde/datzelfde } \\
\text { boek. }\end{array}$ & $\begin{array}{l}\text { Ik lees hetzelfde boek } \\
\text { als Paul. }\end{array}$ \\
\hline
\end{tabular}

23 The abbreviations used in tables (A1) and (A2) are the following ones: ACC: accusative; CL: classifier; CMP: complement; COR: correlative; DAT: dative; DEF: definite; DEM: demonstrative; DS: different subject; EMP: emphatic; FOC: focus; GEN: genitive; INF: infinitive; M: masculine; NEG: negation; NOM: nominative; PL: plural; PR: present tense; PRF: perfect tense; PST: past tense; REL: relative; SP: specificity marker; SG: singular; SS: same subject; TEMP: temporal dependency; TOP: topic. 


\begin{tabular}{|c|c|c|c|c|}
\hline \multirow[t]{2}{*}{ German } & $\begin{array}{c}\text { der/die/das gleiche } \\
\text { (type reading) } \\
\text { derselbe/diesselbe } \\
\text { /dasselbe } \\
\text { (token reading) }\end{array}$ & $\begin{array}{c}\text { der/die/das gleiche } \\
\text { (type reading) } \\
\text { derselbe/diesselbe } \\
\text { /dasselbe } \\
\text { (token reading) }\end{array}$ & $\begin{array}{c}\text { der/die/das gleiche } \\
\text { (type reading) } \\
\text { derselbe/diesselbe } \\
\text { /dasselbe } \\
\text { (token reading) }\end{array}$ & $\begin{array}{c}\text { der/die/das gleiche } \\
\text { (type reading) } \\
\text { derselbe/diesselbe } \\
\text { /dasselbe } \\
\text { (token reading) } \\
\end{array}$ \\
\hline & $\begin{array}{l}\text { Anne und Mike haben } \\
\text { das gleiche Buch } \\
\text { gelesen. }\end{array}$ & $\begin{array}{l}\text { Jedes Kind hat das } \\
\text { gleiche Buch gelesen. }\end{array}$ & $\begin{array}{l}\text { Paul hat sich } \\
\text { entschlossen, die } \\
\text { Odyssee zu lesen. Ich } \\
\text { habe mich für das } \\
\text { gleiche Buch } \\
\text { entschieden. }\end{array}$ & $\begin{array}{l}\text { Ich habe das gleiche } \\
\text { Buch wie Paul } \\
\text { gelesen. }\end{array}$ \\
\hline \multirow[t]{2}{*}{ Russian } & $\begin{array}{l}\text { odnu } i \text { tu zhe } \\
\text { one and that EMP }\end{array}$ & $\begin{array}{l}\text { odnu } i \text { tu zhe } \\
\text { one and that EMP }\end{array}$ & $\begin{array}{l}\text { etu zhe (samuju) } \\
\text { this EMP (very) }\end{array}$ & $\begin{array}{l}\text { tu zhe (samuju).., } \\
\text { that EMP (very) ..., } \\
\text { chto } \\
\text { that }\end{array}$ \\
\hline & $\begin{array}{l}\text { Anja i Misha } \\
\text { Anya and Misha } \\
\text { pro-ch-l-i odnu } \\
\text { PRF-read- PST-PL one } \\
i \quad \text { tu zhe knigu } \\
\text { and that EMP book. }\end{array}$ & $\begin{array}{l}\text { Kazhdyj rebjonok } \\
\text { every child } \\
\text { pro-chjo-I odnu } \\
\text { PRF-read-PST:SG one } \\
i \text { tu zhe knigu. } \\
\text { and that EMP book. }\end{array}$ & $\begin{array}{l}\text { Pasha reshil } \\
\text { Paul decided } \\
\text { pro-ches-t' Odisseju. } \\
\text { PRF-read-INF Odyssey. } \\
\text { Ja vybra-I etu zhe } \\
\text { I choose-PST this EMP } \\
\text { (samuju) knigu } \\
\text { (very) book }\end{array}$ & $\begin{array}{l}\text { Ja pro-chjo-I tu } \\
\text { I PRF-read-PST:SG that } \\
\text { zhe (samuju) knigu, } \\
\text { EMP (very) book } \\
\text { chto } i \text { Pasha. } \\
\text { that and Paul. }\end{array}$ \\
\hline \multirow[t]{2}{*}{ Armenian } & en nujn & en nujn & nujn & en nujn inch vor \\
\hline & $\begin{array}{l}\text { Annan u Majk@ } \\
\text { kardum en nujn } \\
\text { girk@: }\end{array}$ & $\begin{array}{l}\text { Bolor (all) erexaner@ } \\
\text { kardum en nujn } \\
\text { girk@: }\end{array}$ & $\begin{array}{l}\text { Pol@ voroshec kardal } \\
\text { Vodisakan@: Yes } \\
\text { @ntreci nujn girk@: }\end{array}$ & $\begin{array}{l}\text { Yes kardum em nujn } \\
\text { girk@, inch vorPol@: }\end{array}$ \\
\hline \multirow[t]{2}{*}{ Bengali } & $\begin{array}{c}\varepsilon k i \\
\text { one-EMP }\end{array}$ & $\begin{array}{c}\varepsilon k i \\
\text { one-EMP }\end{array}$ & $\begin{array}{c}\text { a) } \varepsilon k i \\
\text { one-EMP } \\
\text { b) Jej boj-ta-j } \\
\text { COR book-DEF-EMP } \\
\text { that (exact.)book }\end{array}$ & $\begin{array}{c}\text { a) } \varepsilon k i \\
\text { one-EMP } \\
\text { b) } d z e j . . . \int e-t a \\
\text { REL... COR-DEF } \\
\text { which...that one }\end{array}$ \\
\hline & 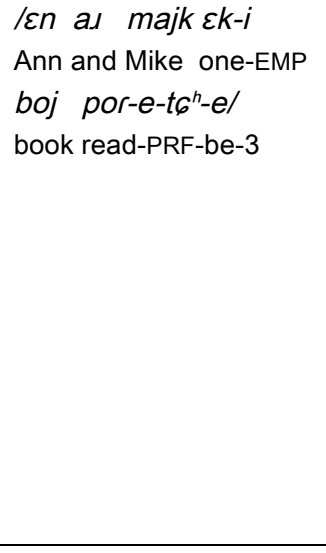 & $\begin{array}{l}\text { /pıot:-ek-ta bat6:a } \\
\text { every-one-CL child } \\
\varepsilon k-i \quad \text { boj } \\
\text { one-EMP book } \\
\text { por-e-t } 6^{h}-e / \\
\text { read-PRF-be-3 }\end{array}$ & 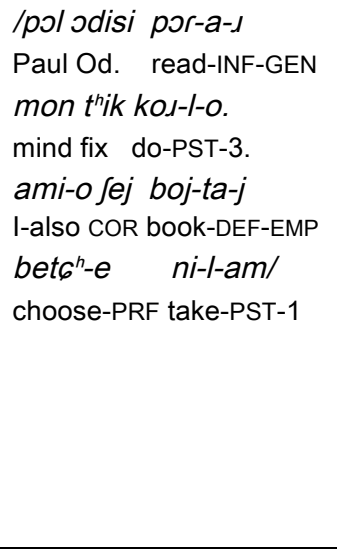 & 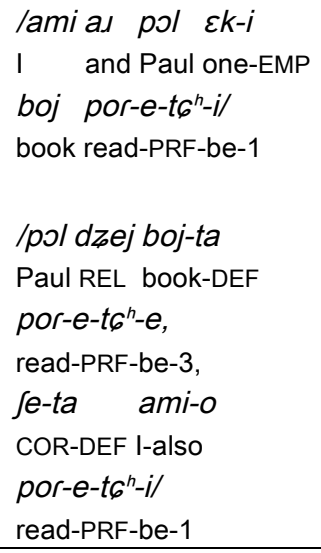 \\
\hline \multirow[t]{2}{*}{ Hebrew } & $\begin{array}{c}\text { 7oto } \\
\text { same-SG }\end{array}$ & $\begin{array}{c}\text { Poto } \\
\text { same-SG }\end{array}$ & $\begin{array}{c}\text { Poto } \\
\text { same-SG }\end{array}$ & $\begin{array}{c}\text { Poto } \\
\text { same-SG }\end{array}$ \\
\hline & $\begin{array}{l}\text { An u-Maik qor?im } \\
\text { A. and-M. read.3PL } \\
\text { ?et ?oto ha-sefer. } \\
\text { ACC same.SG DEF-book }\end{array}$ & $\begin{array}{l}\text { kol ha-yeladim qor?im } \\
\text { all DEF-children read.3PL } \\
\text { ?et ?oto ha-sefer, } \\
\text { ACC same.SG DEF-book }\end{array}$ & $\begin{array}{l}\text { pol hihlit liqro? } \\
\text { Paul decide.PST read.INF } \\
\text { ?et ha-odise?a. ani } \\
\text { ACC DEF-Odyssey I } \\
\text { bahar-ti } \\
\text { choose.PST-1SG }\end{array}$ & $\begin{array}{l}\text { ?ani qore } \text { ?oto sefer } \\
\text { I read same book } \\
\text { kmo pol } \\
\text { as Paul }\end{array}$ \\
\hline
\end{tabular}




\begin{tabular}{|c|c|c|c|c|}
\hline & & & $\begin{array}{l}\text { be-?oto ha-sefer. } \\
\text { in-same.SG DEF-book. }\end{array}$ & \\
\hline \multirow[t]{2}{*}{ Turkish } & $\begin{array}{c}\text { aynı ...-i } \\
\text { same ...-SP }\end{array}$ & $\begin{array}{c}\text { aynı ...-i } \\
\text { same ...-SP }\end{array}$ & $\begin{array}{c}\text { aynı ...-i } \\
\text { same ...-SP }\end{array}$ & $\begin{array}{c}\text { 'la aynı ...-i } \\
\text { same ....-SP as }\end{array}$ \\
\hline & $\begin{array}{l}\text { Anne ve Mike aynı } \\
\text { Anne and Mike same } \\
\text { kitab-ı oku-du } \\
\text { book-SP read-PST }\end{array}$ & $\begin{array}{l}\text { Her çocuk aynı } \\
\text { Every child same } \\
\text { kitab-ı oku-du } \\
\text { book-SP read-PST }\end{array}$ & $\begin{array}{l}\text { Paul Odyssey'i } \\
\text { Paul Odyssey-SP } \\
\text { oku-ma-y-a karar } \\
\text { read-INF-buffer-DAT- } \\
\text { ver-di. Ben de aynı } \\
\text { decide-PST. I too same } \\
\text { kitab-ı seç-ti-m. } \\
\text { book-SP choose-PST-1SG }\end{array}$ & $\begin{array}{l}\text { Paul'la aynı } \\
\text { Paul-with same } \\
\text { kitab-ı oku-du-m } \\
\text { book-SP read-PST-1SG }\end{array}$ \\
\hline \multirow[t]{2}{*}{ Thai } & $\begin{array}{c}\text { diew เดี่ยว } \\
\text { deīyw }\end{array}$ & $\begin{array}{c}\text { diew } \\
\text { deīyw }\end{array}$ & $\begin{array}{l}\text { diew } \\
\text { deìyw }\end{array}$ & $\begin{array}{l}\text { diew } \\
\text { deīyw }\end{array}$ \\
\hline & $\begin{array}{l}\text { Anne gub Mike arn' } \\
\text { nung seu lem diew } \\
\text { gun. }\end{array}$ & $\begin{array}{l}\text { dek took kon arn' } \\
\text { nung seu lem diew } \\
\text { gun. }\end{array}$ & $\begin{array}{l}\text { Paul tud sin jai tee ja } \\
\text { arn' Odyysey. chun } \\
\text { luek tee ja arn nung } \\
\text { seu lem diew gun. }\end{array}$ & $\begin{array}{l}\text { chun arn nung seu } \\
\text { lem diew gun gub } \\
\text { Paul. }\end{array}$ \\
\hline \multirow[t]{2}{*}{ Taiwanese } & $\begin{array}{l}\text { kang khuan e } \\
\text { same type REL }\end{array}$ & $\begin{array}{l}\text { kang khuan e } \\
\text { same type REL }\end{array}$ & $\begin{array}{l}\text { kang khaun e } \\
\text { same type REL }\end{array}$ & $\begin{array}{l}\text { kang khaun e } \\
\text { same type REL }\end{array}$ \\
\hline & $\begin{array}{l}\text { A-Ying kam A-Ha thak } \\
\text { A-Ying and A-Ha read } \\
\text { kang khuan e chhe } \\
\text { same type REL book }\end{array}$ & $\begin{array}{l}\text { mui chit-e gin-a thak } \\
\text { every one-CL child read } \\
\text { kang khuan e chhe } \\
\text { same type REL book }\end{array}$ & $\begin{array}{l}\text { A-Ying kuat-ting beh } \\
\text { A-Ying decide want } \\
\text { thak Odyssey. gua } \\
\text { read Odyssey I } \\
\text { suan kang khaun } \\
\text { choose same type } \\
e \text { chhe } \\
\text { REL book }\end{array}$ & $\begin{array}{l}\text { gua kam A-Ying thak } \\
\text { I and Paul read } \\
\text { kang khuan e chhe } \\
\text { same type REL book }\end{array}$ \\
\hline \multirow[t]{2}{*}{ Malai } & $\begin{array}{l}\text { yang sama } \\
\text { the same }\end{array}$ & $\begin{array}{l}\text { yang sama } \\
\text { the same }\end{array}$ & $\begin{array}{l}\text { yang sama } \\
\text { the same }\end{array}$ & $\begin{array}{c}\text { yang sama dengan } \\
\text { the same as }\end{array}$ \\
\hline & $\begin{array}{l}\text { Anne dan Mike telah } \\
\text { Anne and Mike PST- } \\
\text { membaca buku } \\
\text { read book } \\
\text { yang sama } \\
\text { the same }\end{array}$ & $\begin{array}{l}\text { Setiap budak } \\
\text { each child } \\
\text { membaca buku } \\
\text { read book } \\
\text { yang sama } \\
\text { the same }\end{array}$ & $\begin{array}{l}\text { Paul berputus } \\
\text { Paul decided } \\
\text { membaca Odyssey. } \\
\text { read Odyssey } \\
\text { Saya memilih } \\
\text { I choose } \\
\text { buku yang sama. } \\
\text { book the same }\end{array}$ & $\begin{array}{l}\text { Saya membaca buku } \\
\text { I read book } \\
\text { yang sama dengan } \\
\text { the same with } \\
\text { Paul. } \\
\text { Paul }\end{array}$ \\
\hline \multirow[t]{2}{*}{ Japanese } & $\begin{array}{c}\text { onaji } \\
\text { the same }\end{array}$ & $\begin{array}{c}\text { onaji } \\
\text { the same }\end{array}$ & $\begin{array}{c}\text { onaji } \\
\text { the same }\end{array}$ & $\begin{array}{c}\text { to onaji } \\
\text { the same as/with }\end{array}$ \\
\hline & $\begin{array}{l}\text { Annu to Maiku wa } \\
\text { Anne and Mike TOP } \\
\text { onaji hon o yon-da. } \\
\text { same book ACc read-PST }\end{array}$ & $\begin{array}{l}\text { Kodomo wa sorezore } \\
\text { child TOP each } \\
\text { onaji hon o yom-u. } \\
\text { same book ACC read-PST }\end{array}$ & $\begin{array}{l}\text { Pooru wa odyusseia o } \\
\text { Paul TOP Odyssey ACC } \\
\text { yom-u to kime-ta. } \\
\text { read-PR that decide-PST } \\
\text { Watashi wa/mo onaji } \\
\text { I TOP/also same } \\
\text { hon o eran-da. } \\
\text { book ACC choose-PST }\end{array}$ & $\begin{array}{l}\text { Watashi wa Pooru to } \\
\text { I TOP Paul that } \\
\text { onaji hon o yon-da. } \\
\text { same book ACC read-PST } \\
\text { Watashi wa Pooru ga } \\
\text { I TOP Paul NOM } \\
\text { yon-da no to onaji } \\
\text { read-PST that same } \\
\text { hon o yon-da. } \\
\text { book ACC read-PST }\end{array}$ \\
\hline \multirow[t]{2}{*}{ Swahili } & $\begin{array}{c}\text { Sawa } \\
\text { Vya aina moja }\end{array}$ & $\begin{array}{c}\text { Cha aina moja } \\
\text { sawa }\end{array}$ & $\begin{array}{l}\text { Hichohicho } \\
\text { pia }\end{array}$ & $\begin{array}{c}\text { Sawa na } \\
\text { Aina moja kama }\end{array}$ \\
\hline & $\begin{array}{l}\text { Ame na Mika } \\
\text { wanasoma vitabu }\end{array}$ & $\begin{array}{l}\text { Kila mtoto anasoma } \\
\text { kitabu cha aina moja. }\end{array}$ & $\begin{array}{l}\text { Paulo aliamua } \\
\text { kusoma Odyssey. } \mathrm{Na}\end{array}$ & $\begin{array}{l}\text { Na soma kitabu sawa } \\
\text { na Paulo. }\end{array}$ \\
\hline
\end{tabular}




\begin{tabular}{|c|c|c|c|c|}
\hline & $\begin{array}{l}\text { sawa. } \\
\text { Ame na Mika } \\
\text { wanasoma vitabu vya } \\
\text { aina moja. }\end{array}$ & $\begin{array}{l}\text { Kila mtoto anasoma } \\
\text { vitabu sawa. }\end{array}$ & $\begin{array}{l}\text { mimi mlichagua } \\
\text { hichohicho. } \\
\text { Paulo aliamua } \\
\text { kusoma Odyssey. } \mathrm{Na} \\
\text { mimi pia. }\end{array}$ & $\begin{array}{l}\text { Na soma kitabu aina } \\
\text { moja kama Paulo. }\end{array}$ \\
\hline \multirow[t]{2}{*}{ Chickasaw } & $\begin{array}{c}\text { yamma-hchínaakayni } \\
\text { that-same (type) } \\
\text { yamm-akayni } \\
\text { that-same (token) }\end{array}$ & $\begin{array}{c}\text { yamma-hchínaakayni } \\
\text { that-same (type) } \\
\text { chaff-a'si } \\
\text { be.one-only.DS }\end{array}$ & & $\begin{array}{l}\text { yamma-hchínaakayni } \\
\text { that-same }\end{array}$ \\
\hline & $\begin{array}{l}\text { Lynn Charles } \\
\text { Lynn Charles } \\
\text { táwwa'a-t holisso } \\
\text { be.together-ss book } \\
\text { yamma-hchínaakayni } \\
\text { that-same (type) } \\
\text { ittimanompoli-tok. } \\
\text { read-PST } \\
\text { Lynn Charles } \\
\text { Lynn Charles } \\
\text { táwwa'a-t holisso } \\
\text { be.together-ss book } \\
\text { yamm-akayni } \\
\text { that-same (token) } \\
\text { ittimanompoli-tok. } \\
\text { read-PST }\end{array}$ & $\begin{array}{l}\text { Móma-kat holisso } \\
\text { be.all-CMP.Ss book } \\
\text { chaff-a'si hoo- } \\
\text { be.one-only.DS PL- } \\
\text { ittimanompoli-tok. } \\
\text { read-PST } \\
\text { Móma-kat holisso } \\
\text { be.all-cMP.Ss book } \\
\text { yamma-hchínaakayni } \\
\text { that-same } \\
\text { hoo-ittimanompoli- } \\
\text { PL-read } \\
\text { tok. } \\
\text {-PST }\end{array}$ & & $\begin{array}{l}\text { Holisso ish- } \\
\text { book 2sG- } \\
\text { timanompoli-ka } \\
\text { read-CMP.DS } \\
\text { yamma-hchínaakayni } \\
\text { that-same } \\
\text { ittimanompoli-li-tok. } \\
\text { read-1SG-PST }\end{array}$ \\
\hline \multirow[t]{2}{*}{ Zapotec } & $\begin{array}{l}\text { teb-izy } \\
\text { one-only }\end{array}$ & $\begin{array}{c}\text { teb-izy } \\
\text { one-only } \\
\text { lag } \\
\text { same }\end{array}$ & $\begin{array}{c}\text { lag-zag-i } \\
\text { same-just-that }\end{array}$ & $\begin{array}{c}\text { lag } \\
\text { same }\end{array}$ \\
\hline & $\begin{array}{l}\text { Teb-izy liebr b-ily } \\
\text { one-only book PRF-read } \\
\text { Jwany cuan Bed. } \\
\text { Juan and Pedro }\end{array}$ & $\begin{array}{l}\text { Lag liebr-i b-ily } \\
\text { same book-that PRF-read } \\
\text { raa-ta ra mniny. } \\
\text { all-EMP PL child } \\
\text { Teb-izy liebr b-ily } \\
\text { one-only book PRF-read } \\
\text { raa-ta ra mniny. } \\
\text { all-EMP PL child }\end{array}$ & $\begin{array}{l}\text { Jwany b-ily Don } \\
\text { Juan PRF-read Don } \\
\text { Quijot lag-zag-i } \\
\text { Quijote same-just-that } \\
\text { b-ily-a. } \\
\text { PRF-read-1SG }\end{array}$ & $\begin{array}{l}\text { Lag liebr ni b-ily } \\
\text { same book REL PRF-read } \\
\text { Jwany b-ily Bed. } \\
\text { Juan PRF-read Pedro } \\
\text { Lag sa liebr ni } \\
\text { same fellow book REL } \\
\text { b-ily } \\
\text { PRF-read } \\
\text { Jwany b-ily Bed. } \\
\text { Juan PRF-read Pedro }\end{array}$ \\
\hline
\end{tabular}

\section{Table A.1. Crosslinguistic data about same}

\section{A.2. Crosslinguistic data about different/other}

Contrary to same, different can present several counterparts in a given language depending on the cases that are mentioned in this paper. As explained in section 5.2, I hypothesize that this is due to the fact that the case of DP selection and that of CP selection can correspond to different lexicalizations. Moreover, we do not observe this with same because terms like identical are not included in the survey: speakers do not seem to spontaneously translate same as identical (maybe because the difference between type and token readings is perceived as more important in the case of identity 
than in the case of difference, since only in the former case does it impact the number of objects in question).

\begin{tabular}{|c|c|c|c|c|}
\hline & $\begin{array}{l}\text { Plural sentence- } \\
\text { internal case }\end{array}$ & $\begin{array}{c}\text { Quantified } \\
\text { sentence-internal } \\
\text { case }\end{array}$ & $\begin{array}{c}\text { Sentence-external } \\
\text { case }\end{array}$ & $\begin{array}{c}\text { Case with overt } \\
\text { linker }\end{array}$ \\
\hline \multirow[t]{2}{*}{ English } & a different/different & a different & a different/another & $\begin{array}{c}\text { a different than/from/ } \\
\text { another than }\end{array}$ \\
\hline & $\begin{array}{l}\text { Anne and Mike read } \\
\text { different books/a } \\
\text { different book. }\end{array}$ & $\begin{array}{l}\text { Every child read a } \\
\text { different book. }\end{array}$ & $\begin{array}{l}\text { Paul decided to read the } \\
\text { Odyssey. I chose a } \\
\text { different/another book. }\end{array}$ & $\begin{array}{l}\text { I read a different book } \\
\text { than/from Paul/another } \\
\text { book than Paul. }\end{array}$ \\
\hline \multirow[t]{2}{*}{ French } & $\begin{array}{l}\text { un différent/des } \\
\text { différents }\end{array}$ & un différent & un différent/un autre & $\begin{array}{c}\text { un autre que/un } \\
\text { différent de }\end{array}$ \\
\hline & $\begin{array}{l}\text { Anne et Michel ont lu } \\
\text { un livre différent/des } \\
\text { livres différents. }\end{array}$ & $\begin{array}{l}\text { Chaque enfant a lu un } \\
\text { livre différent. }\end{array}$ & $\begin{array}{l}\text { Paul a décidé de lire } \\
\text { l'Odyssée. J'ai choisi un } \\
\text { livre différent/un autre } \\
\text { livre. }\end{array}$ & $\begin{array}{l}\text { J'ai lu un autre livre } \\
\text { que Paul/un livre } \\
\text { différent de Paul. }\end{array}$ \\
\hline \multirow[t]{2}{*}{ Italian } & $\begin{array}{c}\text { dei diversi } \\
\text { different }\end{array}$ & $\begin{array}{l}\text { un diverso } \\
\text { a different }\end{array}$ & $\begin{array}{l}\text { a) un diverso } \\
\text { a different } \\
\text { b) un altro } \\
\text { another }\end{array}$ & $\begin{array}{c}\text { un altro... rispetto a } \\
\text { another... with respect } \\
\text { to }\end{array}$ \\
\hline & $\begin{array}{l}\text { Anne e Michel hanno } \\
\text { letto dei libri diversi }\end{array}$ & $\begin{array}{l}\text { Ogni bambino ha letto } \\
\text { un libro diverso }\end{array}$ & $\begin{array}{l}\text { Paul ha deciso di leggere } \\
\text { l'Odissea. Io ho scelto un } \\
\text { libro diverso/un altro libro. }\end{array}$ & $\begin{array}{l}\text { Io ho letto un altro libro } \\
\text { rispetto a Paul }\end{array}$ \\
\hline \multirow[t]{2}{*}{ Spanish } & $\begin{array}{c}\text { diferente } \\
\text { distinto }\end{array}$ & $\begin{array}{c}\text { diferente } \\
\text { distinto }\end{array}$ & $\begin{array}{l}\text { diferente } \\
\text { distinto }\end{array}$ & $\begin{array}{l}\text { diferente } \\
\text { distinto }\end{array}$ \\
\hline & $\begin{array}{l}\text { Ana y Miguel leyeron } \\
\text { libros diferentes. }\end{array}$ & $\begin{array}{l}\text { Todos los niños leyeron } \\
\text { libros diferentes. / Cada } \\
\text { niño leyó un libro } \\
\text { diferente. }\end{array}$ & $\begin{array}{l}\text { Pablo decidió leer la } \\
\text { Odisea. Yo elegí un libro } \\
\text { diferente / Yo elegí otro } \\
\text { libro. }\end{array}$ & $\begin{array}{l}\text { Yo leí un libro diferente } \\
\text { que Pablo. / Yo leí un } \\
\text { libro diferente al de } \\
\text { Pablo. }\end{array}$ \\
\hline \multirow[t]{2}{*}{ Portuguese } & $\begin{array}{c}\text { diferentes } \\
\text { different }\end{array}$ & $\begin{array}{c}\text { um diferente } \\
\text { a different }\end{array}$ & $\begin{array}{l}\text { um diferente/outro } \\
\text { a different/another }\end{array}$ & $\begin{array}{l}\text { um diferente do } \\
\text { a different from }\end{array}$ \\
\hline & $\begin{array}{l}\text { A Anne e o Mike } \\
\text { leram livros } \\
\text { diferentes. }\end{array}$ & $\begin{array}{l}\text { Todas as crianças } \\
\text { leram um livro diferente. }\end{array}$ & $\begin{array}{l}\text { O Paul decidiu ler a } \\
\text { Odisseia. Eu escolhi um } \\
\text { livro diferente. } \\
\text { Eu escolhi outro livro. }\end{array}$ & $\begin{array}{l}\text { ?Eu li um livro } \\
\text { diferente do Paul. } \\
\text { Eu li um livro diferente } \\
\text { do do Paul. }\end{array}$ \\
\hline \multirow[t]{2}{*}{ Dutch } & $\begin{array}{c}\text { verschillende } \\
\text { different }\end{array}$ & $\begin{array}{l}\text { een ander } \\
\text { a different }\end{array}$ & $\begin{array}{l}\text { een ander } \\
\text { a different }\end{array}$ & $\begin{array}{l}\text { een ander... dan } \\
\text { a different...than }\end{array}$ \\
\hline & $\begin{array}{l}\text { Anne en Mike lezen } \\
\text { verschillende boeken }\end{array}$ & $\begin{array}{l}\text { leder kind leest een } \\
\text { ander boek }\end{array}$ & $\begin{array}{l}\text { Paul besloot de Odysseus } \\
\text { te lezen. Ik koos een } \\
\text { ander boek }\end{array}$ & $\begin{array}{l}\text { Ik lees een ander boek } \\
\text { dan Paul. }\end{array}$ \\
\hline \multirow[t]{2}{*}{ German } & verschieden & $\begin{array}{c}\text { ein anderes/eine } \\
\text { andere/einen andere }\end{array}$ & $\begin{array}{c}\text { ein anderes/eine } \\
\text { andere/einen andere }\end{array}$ & $\begin{array}{c}\text { ein anderes/eine } \\
\text { andere/einen andere } \\
\text { als }\end{array}$ \\
\hline & $\begin{array}{l}\text { Anne und Mike haben } \\
\text { verschiedene Bücher } \\
\text { gelesen. }\end{array}$ & $\begin{array}{l}\text { Jedes Kind hat ein } \\
\text { anderes Buch gelesen. }\end{array}$ & $\begin{array}{l}\text { Paul hat sich } \\
\text { entschlossen, die } \\
\text { Odyssee zu lesen. Ich } \\
\text { habe mich für ein anderes } \\
\text { Buch entschieden. }\end{array}$ & $\begin{array}{l}\text { Ich habe ein anderes } \\
\text { Buch gelesen als Paul. }\end{array}$ \\
\hline Russian & raznye & raznye & druguju & ?inuju ... chem \\
\hline
\end{tabular}




\begin{tabular}{|c|c|c|c|c|}
\hline & different & different & other & $\begin{array}{c}\text { different than } \\
\text { ne tu ... kotoruju } \\
\text { not that... which }\end{array}$ \\
\hline & $\begin{array}{l}\text { Anja } i \text { Misha } \\
\text { Anya and Misha } \\
\text { pro-ch-l-i } \\
\text { raznye } \\
\text { PERF-read-PST-PL } \\
\text { different knigi } \\
\text { books. }\end{array}$ & $\begin{array}{l}\text { *Kazhdyj rebjonok } \\
\text { Every child } \\
\text { pro-chjo-I raznuju } \\
\text { PRF-read-PST:SG different } \\
\text { knigu. } \\
\text { book. } \\
\\
\text { Vse deti } \\
\text { all children } \\
\text { pro-ch-l-i raznye } \\
\text { PRF-read-PST-PL different } \\
\text { knigi. } \\
\text { books. }\end{array}$ & $\begin{array}{l}\text { Pasha reshil pro-ches-t' } \\
\text { Paul decided PRF-read-INF } \\
\text { Odisseju. Ja vybra-I } \\
\text { Odyssey. I choose-PST } \\
\text { druguju knigu } \\
\text { other book }\end{array}$ & $\begin{array}{l}\text { ?Ja pro-chjo-I } \\
\text { I PRF-read-PST:SG } \\
\text { inuju knigu, chem } \\
\text { different book than } \\
\text { Paul. } \\
\text { Pasha. } \\
\text { Ja pro-chjo-I ne } \\
\text { I PRF-read-PST:SG not } \\
\text { tu knigu, kotoruju } \\
\text { that book which } \\
\text { chital Pasha. } \\
\text { read Paul. }\end{array}$ \\
\hline \multirow[t]{2}{*}{ Armenian } & $\begin{array}{l}\text { en tarber } \\
\text { different }\end{array}$ & $\begin{array}{c}\text { e tarber } \\
\text { a different }\end{array}$ & $\begin{array}{l}\text { a) urish } \\
\text { b) mek ayl } \\
\text { c) tarber } \\
\text { d) mek urish }\end{array}$ & $\begin{array}{c}\text { a) ?em ayl ... kan } \\
\text { b) ?em ...-ic tarber } \\
\text { c) ?em ...-i kardacacic } \\
\text { tarber }\end{array}$ \\
\hline & $\begin{array}{l}\text { Annan u Majk@ } \\
\text { kardum en tarber } \\
\text { grqer: }\end{array}$ & $\begin{array}{l}\text { Yurakanchyur erexa } \\
\text { kardum e tarber girk: }\end{array}$ & $\begin{array}{l}\text { Pol@ voroshec kardal } \\
\text { Vodisakan@: Yes @ntreci } \\
\text { urish/mek ayl/ tarber/mek } \\
\text { urish girk: }\end{array}$ & $\begin{array}{l}\text { ?Yes kardum em ayl } \\
\text { girk, kan Pol@: } \\
\text { ?Yes kardum em Polic } \\
\text { tarber girk: } \\
\text { ?Yes kardum em Poli } \\
\text { kardacacic tarber girk: }\end{array}$ \\
\hline \multirow[t]{2}{*}{ Bengali } & $\begin{array}{c}\text { a) } b^{\text {hin:o }} \\
\text { different } \\
\text { b) } \varepsilon k-e k-t a \\
\text { one-one-TA } \\
\text { one.each }\end{array}$ & $\begin{array}{c}\varepsilon k-e k-t a \\
\text { one-one-TA } \\
\text { one.each }\end{array}$ & $\begin{array}{c}\text { on:o } \varepsilon k-t a \\
\text { other one-TA } \\
\text { another }\end{array}$ & $\begin{array}{c}\varepsilon k \text {-ta ... as ... on:o } \varepsilon k- \\
\text { ta } \\
\text { one-TA... and ... other } \\
\text { one-TA }\end{array}$ \\
\hline & 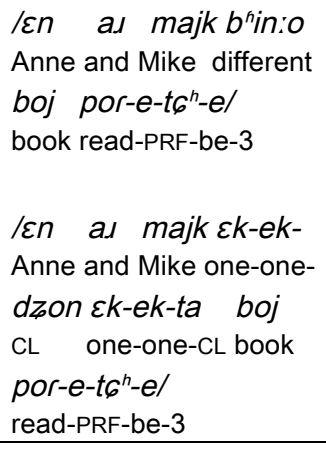 & $\begin{array}{l}\text { /Ek-ek-ta bat6:a } \varepsilon k-e k- \\
\text { one-one-CL child one-one- } \\
\text { ta boj por-e-t6h-e/ } \\
\text { CL book read-PRF-be-3 }\end{array}$ & 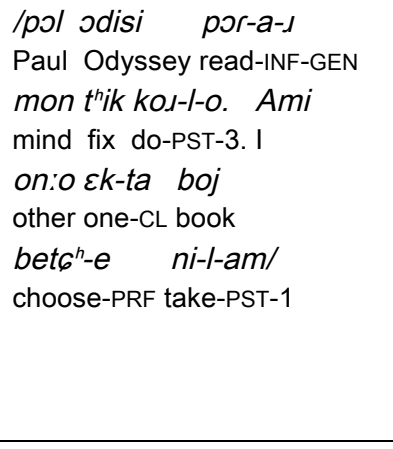 & $\begin{array}{l}\text { Ipol } \varepsilon k-t a \text { boj } \\
\text { Paul one-CL book } \\
\text { por-e-t } \epsilon^{h}-e \text { al ami } \\
\text { read- PRF-be-3 and I } \\
\text { on:o } \varepsilon k-t a \text { boj } \\
\text { other one-CL book } \\
\text { por-e-t } \epsilon^{h}-i / \\
\text { read-PRF-be-1 }\end{array}$ \\
\hline \multirow[t]{2}{*}{ Hebrew } & $\begin{array}{c}\text { šonim } \\
\text { different-pl }\end{array}$ & $\begin{array}{l}\text { Taher } \\
\text { other }\end{array}$ & $\begin{array}{l}\text { Taher } \\
\text { other }\end{array}$ & $\begin{array}{c}\text { šone?/aḥer } \\
\text { different/other }\end{array}$ \\
\hline & $\begin{array}{l}\text { an u-maik qor?im } \\
\text { Anne and-Mike read.PL } \\
\text { sfarim šonim. } \\
\text { books different.PL }\end{array}$ & $\begin{array}{l}\text { kol yeled qore } \\
\text { all children read } \\
\text { sefer ?aher. } \\
\text { book other }\end{array}$ & $\begin{array}{l}\text { pol hihlit liqro? } \\
\text { Paul decide.PST read.INF } \\
\text { ?et ha-odise?a. Ani } \\
\text { ACC DEF-Odyssey I } \\
\text { bahar-ti be-sefer } \\
\text { choose.PST-1SG in-book } \\
\text { ?aher. } \\
\text { other }\end{array}$ & $\begin{array}{l}\text { 7ani qore sefer šone } \\
\text { I read book different } \\
\text { //7aher mi-ze } \\
\text { other from-DEM.SG.M } \\
\text { še-qore pol. } \\
\text { that-read Paul }\end{array}$ \\
\hline
\end{tabular}




\begin{tabular}{|c|c|c|c|c|}
\hline \multirow[t]{2}{*}{ Turkish } & $\begin{array}{l}\text { farklı ... -lar } \\
\text { different } \quad \text {-PL }\end{array}$ & $\begin{array}{c}\text { farklı bir } \\
\text { different a }\end{array}$ & $\begin{array}{cc}\text { farklı bir } \\
\text { different a }\end{array}$ & $\begin{array}{cll}\text { 'dan } & \text { farklı } & \text { bir } \\
\text {-from } & \text { different } & \text { a }\end{array}$ \\
\hline & $\begin{array}{l}\text { Anne ve Mike farklı } \\
\text { Anne and Mike different } \\
\text { kitap-lar okudu-lar. } \\
\text { book-PL read-3.PL }\end{array}$ & $\begin{array}{l}\text { Her çocuk farklı } \\
\text { every child different } \\
\text { bir kitap oku-du. } \\
\text { a book read-PST }\end{array}$ & $\begin{array}{l}\text { Paul Odyssey'i } \\
\text { Paul Odyssey-SP } \\
\text { oku-ma-y-a karar } \\
\text { read-INF-buffer-DAT- } \\
\text { ver-di. Ben farklı } \\
\text { decide-PST. I different } \\
\text { bir kitap seç-ti-m } \\
\text { a book choose-PST-1SG }\end{array}$ & $\begin{array}{l}\text { Paul'dan farklı } \\
\text { Paul-from different } \\
\text { bir kitap oku-du-m } \\
\text { a book read-PST.1SG }\end{array}$ \\
\hline \multirow[t]{2}{*}{ Thai } & tāng & tāng & tāng & tāng \\
\hline & $\begin{array}{l}\text { Anne gub Mike arn' } \\
\text { nung seu taang lem } \\
\text { gun }\end{array}$ & $\begin{array}{l}\text { Dek took kon arn' nung } \\
\text { seu taang lem gun }\end{array}$ & $\begin{array}{l}\text { Paul tud sin jai tee ja arn' } \\
\text { Odyysey. chun luek tee ja } \\
\text { arn nung seu taang lem } \\
\text { gun }\end{array}$ & $\begin{array}{l}\text { chun arn nung seu } \\
\text { taang lem gun gub } \\
\text { Paul }\end{array}$ \\
\hline \multirow[t]{2}{*}{ Taiwanese } & $\begin{array}{l}\text { bo kang khuan e } \\
\text { NEG same type REL }\end{array}$ & $\begin{array}{l}\text { chit-pun bo kang } \\
\text { one-CL NEG same } \\
\text { khuan e } \\
\text { type REL }\end{array}$ & $\begin{array}{c}\text { chit-pun bo kang } \\
\text { one-CL NEG same } \\
\text { khuan e } \\
\text { type REL }\end{array}$ & \\
\hline & $\begin{array}{l}\text { A-Ha kam A-Ying } \\
\text { A-Ha and A-Ying } \\
\text { thak bo kang khuan } \\
\text { read NEG same type } \\
e \text { chhe } \\
\text { REL book }\end{array}$ & $\begin{array}{l}\text { mui chit-e gin-a thak } \\
\text { every one-CL child read } \\
\text { chit-pun bo kang } \\
\text { one-CL NEG same } \\
\text { kuan e chhe } \\
\text { type REL book }\end{array}$ & $\begin{array}{l}\text { A-Ying kuat-ting beh } \\
\text { A-Ying decide want } \\
\text { thak Odyssey. gua suan } \\
\text { read Odyssey. I choose } \\
\text { chit-pun bo kang } \\
\text { one-CL NEG same } \\
\text { khuan e chhe } \\
\text { type REL book }\end{array}$ & $\begin{array}{l}\text { gua thak chit-pun kam } \\
\text { I read one-CL and } \\
\text { A-Ying bo kang- } \\
\text { A-Ying NEG same } \\
\text { khuan } e \text { chhe } \\
\text { type REL book }\end{array}$ \\
\hline \multirow[t]{2}{*}{ Malai } & $\begin{array}{c}\text { yang berlainan } \\
\text { other }\end{array}$ & $\begin{array}{c}\text { yang berbeza daripada } \\
\text { yang lain } \\
\text { different from other }\end{array}$ & $\begin{array}{l}\text { yang lain } \\
\text { another }\end{array}$ & $\begin{array}{l}\text { yang lain daripada } \\
\text { another than }\end{array}$ \\
\hline & $\begin{array}{l}\text { Anne dan Mike telah } \\
\text { Anne and Mike past- } \\
\text { membaca buku } \\
\text { read book } \\
\text { yang berlainan } \\
\text { different }\end{array}$ & $\begin{array}{l}\text { Setiap budak membaca } \\
\text { each child read } \\
\text { buku yang berbeza } \\
\text { book different } \\
\text { daripada yang lain } \\
\text { from other }\end{array}$ & $\begin{array}{l}\text { Paul berputus membaca } \\
\text { Paul decided read } \\
\text { Odyssey. Saya memilih } \\
\text { Odyssey I choose } \\
\text { yang lain } \\
\text { other }\end{array}$ & $\begin{array}{l}\text { Saya membaca buku } \\
\text { I read book } \\
\text { yang lain daripada } \\
\text { other from } \\
\text { Paul } \\
\text { Paul }\end{array}$ \\
\hline Japanese & $\begin{array}{c}\text { chigat-ta } \\
\text { differing (verb) } \\
\text { kotonat-ta } \\
\text { differing (verbe) } \\
\text { betsu no } \\
\text { of difference }\end{array}$ & $\begin{array}{l}\text { chigat-ta } \\
\text { differing (verb) } \\
\text { kotonat-ta } \\
\text { differing (verb) } \\
\text { betsu no } \\
\text { of difference } \\
\end{array}$ & $\begin{array}{c}\text { chigat-ta } \\
\text { differing (verb) } \\
\text { kotonat-ta } \\
\text { differing (verb) } \\
\text { betsu no } \\
\text { of difference }\end{array}$ & $\begin{array}{c}\text { chigat-ta } \\
\text { differing (verb) } \\
\text { kotonat-ta } \\
\text { differing (verb) } \\
\text { betsu no } \\
\text { of difference }\end{array}$ \\
\hline
\end{tabular}




\begin{tabular}{|c|c|c|c|c|}
\hline & $\begin{array}{l}\text { Annu to Maiku wa } \\
\text { Anne and Mike TOP } \\
\text { chigat-ta hon o } \\
\text { differ-PST book ACC } \\
\text { yon-da. } \\
\text { read-PST } \\
\text { Annu to Maiku wa } \\
\text { Anne and Mike TOP } \\
\text { kotonat-ta hon o } \\
\text { differ-PST book ACC } \\
\text { yon-da } \\
\text { read-PST } \\
\text { Annu to Maiku wa } \\
\text { Anne and Mike TOP } \\
\text { betsu no hon o } \\
\text { difference GEN book ACC } \\
\text { yon-da. } \\
\text { read-PST }\end{array}$ & $\begin{array}{l}\text { Kodomo wa sorezore } \\
\text { child TOP each } \\
\text { chigat-ta/kotona-ta/ } \\
\text { differ-PST } \\
\text { betsu no hon o } \\
\text { difference GEN book ACC } \\
\text { yom- } u \\
\text { read-PST }\end{array}$ & $\begin{array}{l}\text { Pooru wa Odyusseia } \\
\text { Paul TOP Odyssey } \\
\text { o yom- } u \text { to kime-ta. } \\
\text { ACC read-PST that decide-PST } \\
\text { Watashi wa chigat-ta/ } \\
\text { I TOP differ-PST / } \\
\text { kotona-ta/betsu no } \\
\text { differ-PST difference GEN } \\
\text { hon o eran-da. } \\
\text { book ACC choose-PST }\end{array}$ & $\begin{array}{l}\text { Watashi wa Pooru } \\
\text { I TOP Paul } \\
\text { to wa chigat-tal } \\
\text { than TOP differ-PST } \\
\text { kotona-ta/betsu } \\
\text { differ-PST difference } \\
\text { no hon o yon-da. } \\
\text { GEN book ACC read-PST }\end{array}$ \\
\hline \multirow[t]{2}{*}{ Swahili } & tofauti & tofauti & $\begin{array}{c}\text { tofauti na yeye } \\
\text { kingine }\end{array}$ & tofauti na \\
\hline & $\begin{array}{l}\text { Ame na Mika } \\
\text { wanasoma vitabu } \\
\text { tofauti. }\end{array}$ & $\begin{array}{l}\text { Kila mtoto anasoma } \\
\text { kitabu tofauti. }\end{array}$ & $\begin{array}{l}\text { Paulo aliamua kusoma } \\
\text { Odyssey. Nikachagua } \\
\text { kitabu tofauti na yeye. } \\
\text { Paulo aliamua kusoma } \\
\text { Odyssey. Nikachagua } \\
\text { kingine. }\end{array}$ & $\begin{array}{l}\text { Na soma kitabu tofauti } \\
\text { na Paulo. }\end{array}$ \\
\hline \multirow[t]{2}{*}{ Chickasaw } & $\begin{array}{c}\text { iitimíla } \\
\text { be.different }\end{array}$ & $\begin{array}{l}\text { ittimilayyokha-ho } \\
\text { be.different-FOC.ACC }\end{array}$ & & $\begin{array}{c}\text { Íla-' }^{\prime} \\
\text { be.different-NOM }\end{array}$ \\
\hline & $\begin{array}{l}\text { Charles ii-táwwa'a-t } \\
\text { C. 1PL-be.together-Ss } \\
\text { holisso iitimíla } \\
\text { book be.different } \\
\text { ii-timanompoli-tok. } \\
\text { 1PL-read-PST }\end{array}$ & $\begin{array}{l}\text { Móma-kat holisso } \\
\text { be.all-CMP.ss book } \\
\text { ittimilayyokha-ho } \\
\text { be.different-FOC.Acc } \\
\text { ittimanopoli-tok. } \\
\text { read-PT }\end{array}$ & & $\begin{array}{l}\text { Charles-at holisso } \\
\text { Charles-NOM book } \\
\text { chaffa-ho } \\
\text { be.one-FOC.ACC } \\
\text { ittimanompoli- } \\
\text { read- } \\
\text { kma ila-' } \\
\text { TEMP.DS be.different-NOM } \\
\text { ittimanompoli-li-tok } \\
\text { read-1SG-PST }\end{array}$ \\
\hline \multirow[t]{2}{*}{ Zapotec } & $\begin{array}{c}\text { reiny } \\
\text { different }\end{array}$ & $\begin{array}{c}\text { reiny } \\
\text { different }\end{array}$ & $\begin{array}{c}\text { reiny } \\
\text { different }\end{array}$ & \\
\hline & $\begin{array}{l}\text { Reiny liebr b-ily } \\
\text { different book PRF-read } \\
\text { Jwany, rein liebr } \\
\text { Juan different book } \\
b \text {-ily Bed. } \\
\text { PRF-read Pedro }\end{array}$ & $\begin{array}{l}\text { Reiny liebr } b \text {-ily } \\
\text { different book PRF-read } \\
\text { cad teiby mniny. } \\
\text { each one book }\end{array}$ & $\begin{array}{l}\text { Jwany b-ily Don Quijot, } \\
\text { Juan PRF-read Don Quijote } \\
\text { na reiny liebr } \\
\text { 1SG different book } \\
b \text {-ily-a. } \\
\text { PRF-read-1SG }\end{array}$ & \\
\hline
\end{tabular}

Table A.2. Crosslinguistic data about different/other 


\section{B. The issue of determiners}

\section{B.1. Même}

As compared to différent and autre, même exhibits a specific behavior with respect to its determiner and to definiteness. I consider this issue as independent from my main issue, but here are some facts illustrating this specificity of même. ${ }^{24}$

- même cannot be used predicatively without the determiner le.

(110) a. Ce livre est *(le) même que celui-là.

'This book is (the) same as this one.'

b. *Je ne le trouve pas même aujourd'hui.

'I don't find him same today.'

c. * Luc et Flore n'ont rien acheté de même.

'Luc and Flore did not buy anything same.'

- the only determiners compatible with sentence-internal même are the definite determiner le/les (singular and plural), and the indefinite one un (only singular) in certain contexts (see Author: 2011 for more details about this).

(111)a. Luc et Flore ont lu ${ }^{*}$ quelques $/{ }^{*}$ divers $/{ }^{*}$ certains $/{ }^{*}$ plusieurs $/{ }^{*}$ trois $/{ }^{*}$ des $/$ les mêmes livres.

'Luc and Flore read some/various/certain/several/three/ø/the same books.'

b. Luc et Flore ont lu ?un/leur/\#ce/le même livre.

'Luc and Flore read a/their/this/the same book.'

- même cannot be modified by adverbs.

(112) Luc et Flore ont lu le (*vraiment/*très/*presque/*tout/*toujours) même livre. 'Luc and Flore read the (really/very/almost/very/always) same book.'

- même cannot be coordinated with other adjectives. ${ }^{25}$

(113) Luc et Flore ont acheté le (*petit et/* premier et/*seul et) même livre.

'Luc and Flore bought the (small and/first and/only and) same book.'

Furthermore, even if the definite determiner is used with même, it does not exhibit the usual properties of the definite article. In particular, it does not appear to trigger a presupposition of unique existence: whether or not there is a unique book that Luc and Flore read is precisely what is at issue in the following sentence.

24 Cf. e.g. Van Peteghem 1997 for a discussion on that matter.

25 There is an exception with unique ('unique') and seul ('sole') that can coordinate with même (la même et unique personne 'the very same person'; une seule et même personne 'a same and unique person'). 
(114) Est-ce que Luc et Flore ont lu le même livre?

'Did Luc and Flore read the same book?'

This issue of definiteness with same and même is examined in more detail in e.g. Barker 2007, Solomon 2009, Author 2010, 2011.

\section{B.2. Différent}

French différent does not always occur in a postnominal adjectival position, but it may also occur in prenominal position, which seems to correspond to the position of the determiner since there is no bare plural in French.

(115)a. J'ai vu différents films pendant les vacances.

b. J'ai vu des films différents pendant les vacances.

'I watched different movies during the holidays.'

At first glance, (115)a (with prenominal différent) and (115)b (with postnominal différent) are roughly synonymous: they both exhibit a vague reading, i.e. not strongly reciprocal; each movie that I watched does not have to be different from the others. But in fact, it seems that there is a contrast between (115)a and (115)b. In (a), the difference primarily comes from plurality, i.e. there are different tokens of movies; this can correlate with other kinds of difference, but the accent is put on the difference in token, while it is put on the difference in type in (115)b. Thus in (115)a, différent seems to amount to a determiner like quelques ('some') while it rather resembles the adjective varié ('various') in (115)b. This issue would be worth further investigating, but it has not been examined in this paper as it is idiosyncratic to French and is orthogonal to the main problem (see a.o. Van Peteghem: 1997, Tovena and Van Peteghem: 2006 for a discussion on that issue). 